\title{
"Confidence in digital money: Are central banks more trusted than age is matter?"
}

\begin{tabular}{|c|c|}
\hline AUTHORS & $\begin{array}{l}\text { Viktor Koziuk (D https://orcid.org/0000-0002-5715-2983 } \\
\text { R https://publons.com/researcher/2112622/viktor-koziuk/ }\end{array}$ \\
\hline ARTICLE INFO & $\begin{array}{l}\text { Viktor Koziuk (2021). Confidence in digital money: Are central banks more } \\
\text { trusted than age is matter?. Investment Management and Financial Innovations, } \\
\text { 18(1), 12-32. doi:10.21511/imfi.18(1).2021.02 }\end{array}$ \\
\hline DOI & http://dx.doi.org/10.21511/imfi.18(1).2021.02 \\
\hline RELEASED ON & Tuesday, 12 January 2021 \\
\hline RECEIVED ON & Sunday, 18 October 2020 \\
\hline ACCEPTED ON & Monday, 28 December 2020 \\
\hline LICENSE & $\begin{array}{l}(\mathrm{coc}) \text { EY } \\
\text { This work is licensed under a Creative Commons Attribution } 4.0 \text { International } \\
\text { License }\end{array}$ \\
\hline JOURNAL & "Investment Management and Financial Innovations" \\
\hline ISSN PRINT & $1810-4967$ \\
\hline ISSN ONLINE & $1812-9358$ \\
\hline PUBLISHER & LLC "Consulting Publishing Company "Business Perspectives" \\
\hline FOUNDER & LLC "Consulting Publishing Company "Business Perspectives" \\
\hline
\end{tabular}

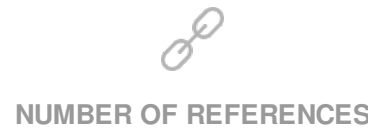

52
NUMBER OF FIGURES

22

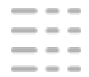

NUMBER OF TABLES

0

(C) The author(s) 2021. This publication is an open access article. 


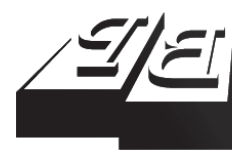

\section{BUSINESS PERSPECTIVES}

(O)

LLC "CPC "Business Perspectives" Hryhorii Skovoroda lane, 10, Sumy, 40022, Ukraine www.businessperspectives.org
Received on: $18^{\text {th }}$ of October, 2020 Accepted on: $28^{\text {th }}$ of December, 2020 Published on: $12^{\text {th }}$ of January, 2021

(C) Viktor Koziuk, 2021

Viktor Koziuk, Doctor of Economics Professor, Head of Economics Department at West Ukrainian National University, Ukraine.
This is an Open Access article, distributed under the terms of the Creative Commons Attribution 4.0 International license, which permits unrestricted re-use, distribution, and reproduction in any medium, provided the original work is properly cited.

Conflict of interest statement: Author(s) reported no conflict of interest
Viktor Koziuk (Ukraine)

\section{CONFIDENCE IN DIGITAL} MONEY: ARE CENTRAL BANKS MORE TRUSTED THAN AGE IS MATTER?

\begin{abstract}
The virtual nature of digital money is fueling the conflict between usability, functionality and trust in the digital form. Institutional trust drivers should move forward in understanding the nature of confidence in digital money. Do central banks digital money (CBDC - central bank digital currency) and private cryptocurrencies demonstrate the same or different trust patterns? The paper used the general regression method to discover the relationship between trust in different forms of digital money and selected variables that may generate this trust. Simple empirical tests were sufficient to find the fundamental importance of age as a confidence driver relevant to CBDC and cryptocurrencies. It is found that traditional factors associated with the inflation history and quality of monetary order (central banks independence and rule of law) do not play a role in the case of CBDC, but are important in the case of cryptocurrencies. Structural features (like FinTech development or social trust) that should support trust in digital money are not found to be important. Societies with larger fraction of younger generations demonstrate higher confidence in centralized and decentralized forms of digital money. This challenges the traditional approach to money and calls into question the future role of monetary stability institutions in the digital age. Digitalization is perceived as an improvement in welfare only when fiat money institutions become fragile. The efficiency and credibility of central banks are not a bonus to confidence in CBDC. This is a challenge for the institutional design of the future digital-based monetary order.
\end{abstract}

\section{Keywords}

central bank digital currency, cryptocurrency, trust, institutions, digitalization

JEL Classification E41, E42, E51, E58, G20

\section{INTRODUCTION}

A decade of cryptocurrency development has shown that their ability to support all money functions is likely to be limited. The social cost of retail payments based on DLT scheme could be high. But at the same time, technological change is seen as a strong push for further changes in the payment landscape, provoking a chain reaction in institutional adaptation to the new environment. Given the historical evidence on how payment vehicles had become true money, it is possible to see that the role of trust/confidence is extremely important. The problem of confidence in decentralized money is related to the intrinsic value, asymmetric information and trust (Aiyagari, 1989; Gandal \& Sussman, 1997; Sargent \& Smith, 1997; Sargent \& Wallace, 1983; Samuelson, 1958), and how it can be solved with the help of new technological opportunities is still under discussion (Eichengreen, 2018). Since trust is an institutional phenomenon that is rising from many decentralized iterations, demonstrating even distribution of uncertainty risks and transaction costs between participants of interactions, the evolutionary path of monetary order will depend on what drives such trust or trust per se. 
Digital currencies, as well as the general process of digitalization, are not neutral to some sort of cognitive barriers of perception. It is very likely that this can potentially create a problem of prepossession vs functionality trade-off. Based on the historical evidence, it is possible to see that the centralized money issue like centralized payment clearing is a kind of the natural monopoly that was Pareto-improvement being subject of political-economy constrains. Lack of trust in such monopoly was determined by the lack or absence of such constrains. Blockchain and cryptocurrencies, in some respect, are the technological responses to this problem. And such a technology seems to be disruptive because it potentially can undermine natural monopoly of central banks.

Meanwhile, modern central banks are relatively successful in maintaining price stability. They represent institutional guarantees that money functions will be realized in structural integrity. Thus, the question touches upon the problem of possibilities of CBDC to be trusted more than privately issued digital money? Poll results are devoted to the identification of the level of confidence to digital money across countries. The Financial Times (2020) demonstrates the results that require deeper understanding of what are the sources of trust to digital money. In addition to embryonic empirical testing of confidence to digital money, understanding of the structural nature of such trust that can help with the better design of digital money and monetary institutions. In this regard, it is very important to answer the following questions:

- Can CBDC and privately issued digital currencies be trusted in the same amount?

- Does money that differ by institutional status of an issuer also differ in trust generating?

- Do economic agents perceive digital money as the same class of assets/means of payments in the context of trust?

- Does the institutional status of an issue matter, or does the technological opportunity affect the agent's preferences by itself, or such preferences should be institutionally biased?

\section{LITERATURE REVIEW}

The field of digital money research continues to expand. Putting the question of trust at the forefront, it is necessary to proceed from the so-called historical approach. According to it, there is some parallel between how historical money gained credibility and how digital money may gain it in modern time. Schnabel and Shin (2018) show that trust in the institution issuing the mean of payment is generated on the level of the collective experience. That is why digital money should follow the same evolving path. Borio (2019) stresses that trust in money is based not only on price stability but also on financial stability. Price stability and financial stability are maintained by institutional pillars through mandate and responsibility of central banks in the area of monetary policy and prudential regulation. Mancini-Griffoli et al. (2018) follow more traditional view saying that disability of cryptocurrencies to carry one of money functions is sufficient to be an obstacle on the way of new monetary order arising independently of technological improvement that is in the core of such new order. In this respect, CBDC looks like an institutional compensator of imperfections of more decentralized monetary orders saving, at the same time, technological advantages.

However, the so-called historical approach implicitly means that the centralized money issue guarantees stronger trust a priori. A confidence problem in the case of cryptocurrencies is seen as an obstacle to the wider use of such currencies. Carstens (2018a) shows that cryptocurrencies are expansive for retail transactions, they do not guarantee cybersecurity, their market prices are volatile, and their potential to serve the illegal activity undermines potential for the common use. Carstens (2018b) stresses, when the value of money is not guaranteed intrinsically, such value should be guaranteed institutionally through the central bank independence. An independent monetary institution is in the core of maintain- 
ing the payment system stability in its ties with financial stability. Given this, confidence in money is based on the efficiency of the retail payment system. Borio (2019) considers the interrelation between price and financial stability, demonstrating that credit is generated by the financial system. According to Borio (2019), a quantitative money indicator as a nominal anchor of price stability is not efficient enough in the case of stability of the financial system as a whole. Interest rates suit better for this purpose. Therefore, confidence in money and in monetary order at all should be based on the central bank. This line of arguments are a strong background for assumptions that in the case of digital money issue by central banks and by private agents, CBDC are expected to be more trusted.

There is a theoretical argument in favor of this. Vaz and Brown (2020) propose an "institutional stack" approach, assuming that such a stack means arrangements, levels and types of institutions that generate trust for money use. Modern fiat money covers seven layers: (in ascending order): $\mathrm{P} 2 \mathrm{P}$ transactions; $\mathrm{P} 2 \mathrm{~B}$ and $\mathrm{P} 2 \mathrm{G}$ transactions; payment systems and distant settlements facilities; national mediation layer; regulatory layer; legal layer; and international mediation layer. Cryptocurrencies satisfy first three layers only and stable coins like Libra suit five first layers. Such an approach is a sort of the theoretical tradition of the institutional money analysis, under which trust is a key point.

Gomez (2019) defines two approaches in the institutional analysis of money. According to the first one, money is rules. According to the second approach, money is equilibrium processes or equilibrium state that occurs in decentralized interactions. At the same time, money is Pareto improvement, due to which they are acceptable on the decentralized level, and the use of money is a new better equilibrium.

The collective acceptance of money is impossible without additional preconditions. Ways to identify such preconditions differ in different studies. For example, the concept of "common knowledge" introduced by Lewis (1969) helps to understand how "common conventions" arise. The channels to spread such "common knowledge" are evident to be in nature of economic transactions (Milgrom \& Stokey, 1982). Money is the "common conventions"; they represent a collective agreement about their decentralized use because they generate benefits for all being trustable. Kocherlakota (1996, 1998) promotes the idea that money is memory, focusing on important issues of how the problem of trust in the decentralized systems should be solved. Schnabel and Shin (2018) distinct that "common knowledge" is an important driver of new monetary order arising since the spread of a new form of money is challenged from the side of credibility and collective acceptability. According to Schnabel and Shin (2004), lack of trust may quickly turn to the market disruption by the liquidity collapsing and the contagion. Some historical examples demonstrate that trust, quickly established and spread, brings strong advantages to the monetary order stability (Quinn \& Roberds, 2014). This is quite relevant for digital money because they are attributes of the virtual world. Algietta (2002) states that confidence in money is generated on the edge of interaction between a person and a society. Due to this, the future success of any monetary order is determined by how new money forms will generate positive network externalities. However, this one more highlights the problem of trust.

Nevertheless, the question of what drives the trust is still open. Mostly, the discussion touches upon a few issues. Is trust generated by functional convenience that becomes "common knowledge"/"collective memory?" Or is trust generated by real manifestation of power of authority that guarantees the efficiency of each form of money? This is very important in the case of confidence in digital money as a class and in the case of CBDC and cryptocurrencies separately. There is a strict understanding how technological changes will affect the power of central banks in the future (see Gross \& Siebenbrunner, 2019; Borio, 2019; Tucker, 2017; Bordo \& Levin, 2017; Raskin \& Yermack, 2016). At the same time, the studies on CBDC optimal design are relatively similar in the conclusion that diminishes the central banks' efficiency is not a doom, because central banks may control system effects by choosing the design (Agur et al., 2019; Mancini-Griffoli et al., 2018; Bindseil, 2020; Adrian \& Mancini-Griffoli, 2019; ManciniGriffoli et al., 2019; BIS, 2018). 
If the assumption about extrapolation of central banks credibility on the confidence in CBDS is true, CBDC have to outperform privately issued digital money by the level of trust. But, as it is shown in the "multiple money" concept (according to Zelizer (1994), multiple money means that the units of payment are strictly tied to the socioeconomic context of the use), CBDC could be perceived as a compensation of cryptocurrency imperfections and as a competitor to privately issued digital money. Thus, do CBDC and cryptocurrencies have similar features or separate features in perception of economic agents? In other words, trust in digital money is likely to be driven by structural characters not relevant to historical analogues. It should not be rejected that in the core of mechanics of common knowledge is the factor that is cognitive by its nature. This is important because digital money relates to the attributes of the virtual world. For example, trust could be biased to FinTech's spread in the country or by the age structure of population. Frost (2020) states that the age structure of the population supports FinTech evolving. If FinTech is a driving force of digitalization supported by the younger generations, the rise of positive network externalities of new money forms could be affected by structural feature that not recognized as important from the historical reflection on the process of the monetary order evolution.

In terms of behavioral economics, age should be viewed as an important factor of trust. According to Fehr et al. (2003, age is not neutral to trust and trustworthiness, which was proved on polling and experimental base. The age structure as a driving force of trust also generates not a trivial problem. Individual convenience affecting individual preferences, being multiplied in decentralized interactions, may undermine mechanisms that are institutions designed to guarantee stability of monetary order on the collective level. If trust is generated without relation to the institutional dimension of the digital money issue, this situation could be a precondition for the gap between monetary quality of money, wholeness of functions such money carry on, and institutions designed for maintaining the monetary order stability. This supports the idea of multiple money (according to Zelizer, 1994), but this does not contribute to understanding the design of monetary stability in the digital era. Poll data shows that the confidence in digital money is not homogenous across countries (The Financial Times, 2020). Due to the large heterogeneity of countries in the poll, the question of source of trust arises.

The purpose of the paper is to empirically test the ties between the level of trust in digital money (across CBDC and privately issued cryptocurrencies) and some structural features of countries, with the particular focus on institutional characteristics. Theoretically, CBDC should be more confident. But this is not the only story, taking into account different inflation memory, perception of central banks' independence. In a similar way, institutional features like trust in others, values, or tolerance to hierarchies, are put forward. This means that there is no strict theoretical precondition why some form of digital money is more trusted then other, except the so called historical view on evolving of monetary order. That is why it is very important to test how similar are the relations between trust drivers and the level of trust across different digital money forms. In the case of the same patterns of relations between chosen independent variables and digital money of centralized and private issue, the confidence is driven by the same criteria, and economic agents perceive them as a same class. In the case of different patterns, economic agents differentiate the issuers from the institutional status' point of you. The last also means that CBDC and cryptocurrencies gain trust in different ways. The results mostly confirm the second hypothesis. But the role of age seems to be the same in both cases, which means that confidence in digital money is biased due to cognitive factors that substantially change our perception about what is stability of the monetary order in the digital era.

\section{THE PROBLEM OF MULTIPLE MONEY IN THE DIGITAL ERA}

DLT (distributed ledger technologies) pushes to rethink how payment services should look like. The competition between blockchain-based payment models and traditional retail payment solutions shows that the value of money for economic 
agents is something more than just wholeness of functions such money performs. Moreover, modern technologies make it possible to adapt modalities of money to different needs. On the one hand, this affects payment services market segmentation. On the other hand, this produces the situation when the structural wholeness of money becomes more distant from the usability of the unit of payability. And this unit of payability is becoming more and more complicated and virtual. Such kind of distancing has very important consequences. Functionality and operability of each money are improved when the performance of three money functions is taken for granted. Thus, the triad of money functions does not require validation, opening the door for more complex perception of what is preference in the case of a means of payments. This substantially complicates the payment landscape. Such landscape is added by the elements of competition between forms of money, and these elements are viewed as a core from the social welfare oriented monetary order.

In other words, it is some kind of life cycle of how economic agents perceive money to perform their functions. In the early stages, some competition takes place among the best money forms for how to combine payment preferences of economic agents with possibilities to safeguard the wholeness of money functions. In the middle stage, the optimal money form is valid for a relatively long time. This optimal form is defined at the institutional and technological level. But, at the same time, this optimal form should reflect the most prominent performance of money functions' structural wholeness. At further stages, economic agents take as data of given money the functions performed by money. As such, technological innovation and institutional changes are widening the requests for ways to meet payment needs. The competition for most convenient payment service is going ahead affecting the preferences of economic agents. Functionality is combined with the imprint that money performs its functions a priori. Ongoing competition focusing on how to best way combine such an imprint with payment needs in order to supply a product/service. If such an imprint is not prominent enough due to the constitutional vulnerability of monetary order, economic agents adjust to it using technological solutions. This makes the life cycle context more concrete but does not deny it. Gomez (2019), analyzing institutional theories of money, stresses that dollarization is an example of how economic agents adjust they preferences amid of imperfections in money to perform their functions due to vulnerability of monetary institutions. Namely, choice toward cryptocurrencies in similar cases is an evidence of attempts to compensate the imperfections of traditional money forms.

However, the more money forms move from their intrinsic value, the more important the role of institutions that maintain confidence in money. It must be said that these are the institutions that guarantee justice and fairness of money transactions, as mentioned by Zucker (1986). The role of trust is enhanced in the case of increased complexity, uncertainty and interrelations (Zanini \& Migueles, 2013). Digital money is closer to complexity, uncertainty and interrelations, and they unlikely compensate these features. The complexity is related to a cognitive barrier while operating with them. It is important in the case of taking them as an attribute of the virtual world. Digital money is a product of more complex social interactions. This means that digital money is based on the ground of more scaled social interactions. Due to this, the problem of interrelations is reproduced because money transactions become more conditioned by the spread of technologies and symmetric availability of them among economic agents. Also, digital money is more dependent on interactions that maintain continuation of the digital world infrastructure. High dimensions of social interactions, behind the digital money use and vulnerability of digital world to technological shocks and cyber-interferences, generate uncertainty that is less relevant to the material world. This kind of uncertainty is important until attributes of the digital world will not become a part of ordinary social practices of the whole society.

Vaz and Brown (2020) say that trust in digital money is based on expectations about its future advantages. Based on the evaluation of the business experience of cryptocurrency use, Yermack (2017) defines the following advantages: no intermediary transaction possibilities; higher levels of security, integrity and privacy; faster payments processing; better protection against debasement; higher efficiency; better ability for cross-border payments; 
financial inclusion. Meanwhile, there is a strong doubt that such kind of cryptocurrencies and DLT-based payment technology advantages will be available in reality, taking into account the evolution of traditional retail payment systems. Most studies demonstrate that the cost-benefit balance of digital money is currently not defined clearly, and the design of digital money, affecting available functionality, is a core of uncertainty about such a balance (Vaz \& Brown, 2020; BIS, 2019; Carstens, 2020; Claeyns et al., 2018; Demertiz \& Wolf, 2018; Ehrentraud et al., 2020).

CBDC are expected to compensate "market failure" of privately issued cryptocurrency. This can be seen from the analysis of different views on modern digital money. For example, according to the "money flower" approach (Bech \& Garratt, 2017; BIS, 2018), it is extracted from four main features on the supply side of digital money: Who is an issuer (central bank or other agents, or nobody like in the case of Bitcoin like cryptocurrency; Money form (physical, electronic, digital; Availability (restricted, common); Transfer mechanism (with centralized counterpart that maintain final clearing or peer-to-peer).

The advantage of CBDC is that they cover most of possible combinations of features. Therefore, they go ahead in terms of functionality. However, such advantage appears only then CBDC enjoy the credibility bonus of the central bank. When monetary policy is not credible, CBDC are likely to be viewed only as a more preferable from the payment convenience side but not from the side of equal alternative to traditional money enhanced by a new technology. Similar view is shown by Kliff et al. (2020). They stress that central bank's digital money issue an advantage by the definition because of legal tender, backing by monetary authority assets added by tie to conventional fiat money with peer-to-peer transactions possibilities and programming (design by choice).

There is another dimension of the problem raised by Adrian and Mancini-Griffoli (2019), MancicniGriffoli et al. (2019), BIS (2018), Bindseil (2020). CBDC contain a wider set of features that determine much deeper consequences than just the convenience of payments. Such consequences are related to the monetary policy transmission, finan- cial stability, credit allocation, financial disintermediation. The problem of cybersecurity sounds stronger, as does the new dimension of transaction privacy (Agur et al., 2019; Mancicni-Griffoli et al., 2018). Traceability vs Anonymity choice is not optimal a priori in both cases.

In nature, confidence in digital money becomes a more complicated phenomenon because such money is inherited by set of attributes and functional characteristics that are not evident in the history. Current evidence is mostly rooted in historical memory of previous generations. Digital money belonging to virtual world domain raises the question that preferences about functionality as a way to overcome barrier of trust cannot appear by themselves, and such trust should be determined by additional factors rooted in cognitive limitations of perception. Here is the key problem of the analysis of confidence in digital money. If cognitive barriers of the digital money perception really exist, they should be relevant to all types of money without ties to institutional status of issuer. If cognitive barriers are not substantial, it is possible to assume that confidence is determined by the algorithm that should take as a given difference the institutional status of an issuer. So, institutional nature of society matters.

For example, a strong central bank is usually credible and delivers price stability. Its ability to provide also grounds on some institutional features like rule of law or checks and balances. Due to this, CBDC will likely to enjoy more credit of trust compared to other money forms. But such credibility does not emanate from the formal central bank's status itself. Such credibility emanates from the pool of institutions that maintain monetary order designed for price stability. In this context, the question of trust in alternatives to modern fiat money is related to problem of how historical memory interacts with institutions that are in the core of monetary authorities independence.

In contrast to institutional characteristics that support central bank independence, institutions that define modalities of group behavior are also important. Since the development of the collective acceptance of any money form is based on the inherited fact of collective experience of the benefits of interaction with money intermediation, institu- 
tions that make up the features of social interactions could not stay apart in the case of how digital money will gain the trust. Stronger "trust in others" assumes that more decentralized models of money are possible in society. At least, the gap between confidence in CBDC and in cryptocurrencies should not be deep. The same is true for attitudes to hierarchies. More hierarchical societies are more likely to prefer money issued by institutions that are perceived as centralized authority. In less hierarchical societies, stronger trust in privately issued digital money is probably more expected. The similar picture is relevant for social capital. Societies with rich social capital are more likely to take more decentralized models of digital money, since interactions are not viewed as treating by welfare expropriation or fraud. Social capital is based on win-win cooperation that reduces transaction costs of interactions. Thus, there is no reason to expect a big difference in confidence to different types of digital money based only on the status of an issuer.

Another dimension of the problem of institutions is the specifics of digital money as an attribute of the virtual world. Asymmetries of this form of money perception and cognitive barriers of identifications of benefits of their use could establish strong structural limitations of trust. Some kinds of structural features of each country may be supported to share the experience relevant to operations in the virtual world. Virtual world living skills and how such skills spread across the whole society could be strong preconditions for confidence in digital money. This is the case when the preference of functionality goes ahead while money functions are performed as a given. Development of innovation sectors or engagement in FinTech could be that sort of structural features that supports network externalities to early appear affecting faster achievement of confidence in digital money. It is hard to reject assumptions that in the more advanced FinTech countries, decentralized digital money should gain trust in a similar way as a CBDC.

Demographical characteristics are similar in that regard. Ferh et al. (2003) demonstrated that trust is substantially determined by the age of people. Frost (2020) points out that the age structure of the population may play a role in influencing the spread of FinTech. In the case of digital money, this is equally important. Younger generations may be more adaptive to manipulating with the attributes of the virtual world thus being more trusting in digital money gaining by no cognitive barriers and stronger preferences of functionality. But this does not mean abandoning the question of how "collective memory" is represented in preferences in different age groups. The experience of price stability as well as monetary instability should work across generations. Due to these "works across", the mechanism of transferring "invisible knowledge" about the quality of money and modality of monetary order is operating. In other words, inflationary experience should be a criterion of constituting the trust in digital money when such money is associated with more efficient monetary order. Nevertheless, this does not reject that "collective memory" may work differently in societies where inflationary experience is a collective trauma or where such experience is not due to permanent macroeconomic instability and political disorder. An inflationary experience argument could be weak when economic agents do not associate money digitalization with more preferred monetary order to appear. Sticky fiat money preferences supported by the credible central bank with the relevant institutional background, as well as privately issued digital money preferences in the case of adaptation to imperfections of fragile monetary order, can demonstrate that trust is not only a product of "collective memory about monetary instability trauma." This memory can be long or short in different societies - another activating issue about the role of cognitive barriers or functional preferences.

The structured factors of confidence in digital money require empirical testing. Due to the relative novelty of digital money and the lack of data, the empirical relationships may deviate from those theoretically expected. This requires additional arguments, especially in the case when empirical relations are opposite to logical ties.

\section{RESEARCH METHODOLOGY}

To confirm confidence in digital money, data from empirical testing conducted by the Official Monetary and Financial Institutions Forum in 12 
countries (India, Malaysia, Brazil, South Africa, Russia, Japan, USA, Canada, UK, Germany, Italy, France) were used (The Financial Times, 2020). Because of the lack of time series and relatively stable time institutional features of each country, the simple regression method was applied. The empirical technique, narrowed to one-factor regressions, was enhanced by combinations of independent variables that help to make additional test on how relations are consistent from the logical and theoretical viewpoints. Graphical representation of regressions is sufficient to see the most possible answers to research questions. "Balance of confidence" is the dependent variable, meaning the difference between fractions of positive and negative responses. Independent variables are grouped according to their institutional nature.

Political and institutional factor variables include: Index of central bank transparency from Dincer and Eichengreen (2014). Due to clear evidence that independence of central banks and transparency positively affect the level of inflation and credibility of monetary policy and is positively correlated with quality of institutions (Berger \& de Haan, 2001; Bodea \& Hicks, 2014; Cukierman, 2008; Dincer \& Eichengreen, 2014), such index should show how confidence in digital money relies on foundations of stable monetary order. It is not denied that direction of relations could be different across CBDC and cryptocurrencies. Rule of Law Index (World Bank Global Development Indicators Data) is an additional institutional variable. The importance of rule of laws is in verifying how close formal rules and factual behavior are. Rule of law is viewed as an important background for true central bank independence, because monetary authorities operate in political environment (Keeper \& Stasavage, 2003; Nurbayev, 2017; Hayo \& Voigt, 2008; Moser, 1999). It is also important to mention that the rule of law is an indirect measure of quality of social interactions due to the relevance of the general level of transaction costs and economic efficiency.

Variables of quality of social interaction drivers are: Power Distance Index from Hofstede Matrix chosen to deal with the question of how cultural attitudes support trust in more centralized or more decentralized digital money; Social Capital
Sub-Index of Legatum Prosperity Index that describes the level of development of social interactions in society and its ability to act collectively, it should help test how confidence in digital money is shaped by social trust and partnership; Trust in others (Net Trust in Others) from World Values Map should measure how openness to social interactions affects confidence in different digital money forms. Given the institutional context of digital money, the direction of relations could differ across CBDC and privately issued cryptocurrencies.

Variables that reflect the structurally determined tolerance to digital money are Global Innovation Index and Global FinTech Index. These variables are indirect signs of how technology advancement helps form confidence in attributes of the virtual world. High scores of such indices highlighting the size of the population are ready to perceive new money forms.

The variable that characterizes "collective memory about inflationary experience" is Ln of accumulated inflation during 1980-2019 from IMF Data Map (for some countries shorter time series was used because of data limitations). By its nature, this variable demonstrates how efficient is the monetary order. There are no expected directions of relations between variables because people can be satisfied with current monetary order demonstrating some aversion to digital money. The opposite is also true. Discontent in macroeconomic situation may enhance expectations about positive consequences of money digitalization. This means that trust in CBDC is not granted. Comparing the direction of relationships between the "inflationary experience" variable and confidence in different forms of digital money with similar relations with variables of political-institutional factors is possible to do indirect cross-check about how important is the quality of monetary institutions.

Demographical factors are measured by the following variables from the UN State of World Population: fraction of population aged between 10 and 24 years old; life expectancy; fraction of population aged over 65 years. These variables are expected to test the hypothesis about the role of the age structure as a supportive driver of ad- 
justability to live in a virtual world. Utilization of three different age measures should validate that the generation factor is not random.

The next part of the paper demonstrates the results of the empirical test and its theoretical interpretation from formal and more general institutional logic.

\section{EMPIRICAL RESULTS}

The results of the empirical testing (see Appendix) are mixed.

In the case of Political-institutional factors (CBDC - Figures A-1A2, and privately issued digital money - Figures A3-A4), the opposite relationships are evident. Transparency of central banks and the rule of law are negatively correlated with confidence in digital money. In the first approximation, it is possible to interpret that economic agents do not see the digitalization improvement in monetary order and demonstrate strong preference to the model of fiat money that is based on strong institutional foundations. Such interpretation is enhanced while compering density of correlation between variables $\mathrm{CBDC}$ and privately issued digital currencies. In the last case, the density of the opposite relation is much stronger. This means that in the case of high central bank credibility, confidence in CBDC is not given mechanically. In the case of cryptocurrencies, the situation is different. Lack of the central bank credibility is a precondition for looking at money digitalization as a way to improve monetary order. But this statement requires additional explanation.

Social interaction variables also demonstrate mixed results. All three variables do not perform with consistency. In the case of CBDC, confidence is directly correlated with the power distance perception that does not contradict with theoretical assumptions. Central banks are associated with the centralized monetary authority, so tolerance to hierarchies affects higher confidence in digital money (Figure B1). But in the case of privately issued digital money, this relationship is tighter (Figure B4), which is not in line with previous subjection. The same is for social capital. Tightness of relations is higher in the case of cryptocurrencies, not $\mathrm{CBDC}$ (Figures $\mathrm{B} 2$ and $\mathrm{B} 5)$. On the one hand, better social capital scores are in a theoretically correct direction of relations with higher trust in decentralized money. On the other hand, this contradicts with the evidence that there are no direct relationships between confidence in digital money across forms and social trust as a characteristic of the country (Figures B3 and B6). In the case of cryptocurrencies (Figure B6), a direct relationship between "trust in others" and confidence in digital money was expected but not empirically confirmed. Also, a tighter relationship between social capital and confidence in cryptocurrencies (Figure B5) is in contrast to inverse relations between this confidence and a rule of law (Figure A4). Theoretically, social capital and rule of law reinforce each other. The absence of identical direction of the relationship between confidence in digital money across forms and a rule of law and social capital indicates that in some cases higher quality of social interactions compensates the weakness of formal institutions. It should not be rejected that this may be an additional proof why the difference exists in tightness of relationships between political-institutional variables and confidence in centralized and decentralized digital money. If actual monetary order grounded on particular quality of institutions is not credible enough, stronger social capital strengthens confidence in privately issued digital money. More efficient informal interactions compensate gaps in formal relations.

With structural indicators that are expected to support perceptions of digitalization, the situation is clear but opposite to theoretical predictions. In both cases, across chosen independent variables (Figures C1-C4), there are no theoretically expected directions in relations. In other words, neither innovative development, nor FinTech advancement are important. And the status of the issue does not matter. The tightness of relations is similar in all cases. These unexpected results can be explained, taking into account that social area that is more engaged in digital world is not so wide to be the driver of switching from traditional money to digital money.

Inflationary experience factors confirm previous assumptions about the role of monetary regime efficiency as a driving force of confidence in digital money. In the case of CBDC, there is no re- 
lationship between accumulated inflation and the dependent variable (Figure D1). In the case of privately issued digital money, the relationship is weak but is clearly direct (Figure D2). This helps to confirm that centralized digital money does not automatically gain credibility of the central bank. The more credible is the central bank, the less is the improvement in monetary order due to digitalization observed by economic agents. But when institutions of monetary order are not credible, digitalization is perceived as a way to expected improvement. This statement is in line with the thesis that money is the embodiment of collective memory, and economic agents adapt to the institutional imperfections of the monetary regime. In this regard, dollarization and digitalization are similar by institutional nature. However, the proven weak correlation restrains strong commitment to the claim that inflationary experience is a key confidence factor in every form of digital money.

In contrast to the cases with theoretically biased independent variables, demographic indicators are the best towards the tightness meaning that age matters. Figures E1-E6 show that in case of the larger fraction of younger generation, as well as the lower fraction of older people, the confidence in cryptocurrencies is strong. In all cases, the relations are tight. It should be pointed that these tight relationships are all with the theoretically predicted sign even when variables are not theoretically biased. Kliff et al. (2020) explore the idea that central banks recognize the age factor as an obstacle of monetary system digitalization. So, this is a good evidence why the age structure is so important for generating confidence in digital money. Fraction of younger people and the fraction of elderly people are both important. Figures $\mathrm{E}-1 \mathrm{E} 6$ demonstrate that confidence in privately issued digital money is stronger when the fraction of older generation is smaller, even compared to confidence in CBDC when fraction of youngers is higher.

\section{DISCUSSION}

The empirical results obtained facilitate the discussion and help to highlight some generalizations. When the cognitive factor of confidence outperforms the factor of collective memory (in- flationary experience) or political-institutional factors (central banks and supportive institutions), a gap appear between fundamental drivers of trust in money and specific drivers of trust in particular form of money, for example, digital. This gap also means that trust in monetary order of fiat money with institutionally defined central bank independence is not equal to trust in digital equivalent of the same money. Some kind of strong habits toward efficient monetary order, multiplied by a cognitive barrier of the virtual world attributes perception, substantially complicates appearance of positive network externalities with better preconditions for such externalities. Conversely, in the absence of strong habits such as inefficient monetary orders, random money forms can gain more credibility. It is also clear that economic agents differentiate digital money from status of issuer point. It can be emphasized that when the age factor is taken into account, two different modalities of trust are observed. In the case of CBDC, confidence is not determined by political economy, inflationary experience or quality of social interactions. For privately issued digital money, confidence is affected by inflationary past, enhanced by the quality of social capital, demonstrating a significant contribution of institutional foundations of central bank independence to the efficiency of monetary order, which means that dollarization and digitalization are similar in nature. Some kind of adverse selection problem is likely to occur. More efficient central banks may be restrained in pushing trust in digital money they issue. Here the life cycle effect of perception of how each form of money performs its functions plays a role. When the performance of such functions is well perceived, there is a form of money in which that money is used. This brings some relativism to the problem of trust, in particular, due to the economic agent's age factor. In contrast, societies with less efficient central banks are more likely to benefit from digitalization and decentralization of monetary order. Age is like an improvement here. Age dominance as a driving force of trust in digital money demonstrates that the spread of such money will be very sensitive to positive networks' externalities. Moreover, it is difficult to deny that the perception of age as a problem in situations of trust in monetary analysis may seem like as a historical bias. 


\section{CONCLUSION}

Digital currencies and new payment technologies are likely to change the monetary landscape. The case of trust in digital money will very soon become the defining moment of how quickly the transition to a new technological level of monetary order functioning will take place. Confidence in digital money integrates factors that are fundamental. There is a life cycle of how money functions through the evolution of forms. When the performance of money functions is taken for granted, the convenience of form is maintained. This creates new challenges to monetary order from the side of technology, which can potentially change the form of money.

Given the poll results (The Financial Times, 2020), it is shown that institutional sources of trust in digital money can be undermined by cognitive challenges related to the attributes of the virtual world. This indicates some difficulties in identifying the role of traditional drivers of money confidence compared to preferences supported by the age of economic agents. It is found that age is the most important driver of trust in digital money. Younger generations are more tolerant to confidence in digital money due to stronger adaptability to living with the virtual world attributes. Advances in innovation and FinTech do not play any role here. At the same time, economic agents do not consider CBDC and privately issued digital money as the same class. Confidence in CBDC is not based on political-institutional factors supportive to central bank independence and monetary efficiency, quality of social capital (except of tolerance to hierarchies) or inflationary experience. The main take-away from this is that monetary order of fiat money with a credible central bank is perceived as efficient, and digitalization is not taken as an improvement but as a convenience. On the other hand, the confidence in privately issued digital money depends on the inflationary experience and is strengthened by stronger social capital, demonstrating the lack of political-institutional support of central bank independence to maintain money stability. Nevertheless, this does not reject, but rather reinforces the role of the population age structure as a prerequisite for the success of monetary order digitalization. This does not remove the problem of the gap between fundamental factors of fiat money system stability and preferences in relation to a particular money form, which is transformed due to new technological opportunities.

\section{AUTHOR CONTRIBUTIONS}

Conceptualization: Viktor Koziuk.

Data curation: Viktor Koziuk.

Formal analysis: Viktor Koziuk.

Funding acquisition: Viktor Koziuk.

Investigation: Viktor Koziuk.

Methodology: Viktor Koziuk.

Project administration: Viktor Koziuk.

Resources: Viktor Koziuk.

Writing - original draft: Viktor Koziuk.

Writing - review \& editing: Viktor Koziuk.

\section{REFERENCES}

1. Adrian, T., \& Mancini-Griffoli, T. (2019). The Rise of Digital Money (IMF FinTech Notes Note/19/01). Retrieved from https://www.imf. org/en/Publications/FinTechnotes/Issues/2019/07/12/The-Riseof-Digital-Money-47097
2. Agur, I., Ari, A., \& Dell'Ariccia, G. (2019). Designing Central Bank Digital Currencies (IMF Working Paper No. WP/19/252) (pp. 1-38). Retrieved from https://papers.ssrn. com/sol3/papers.cfm?abstract_ id $=3523125$
3. Aiyagari, R. (1989). Gresham's Law in a Lemons Markets for Assets. Canadian Journal of Economics, 22(3), 686-697. https://doi. org/10.2307/135549

4. Algietta, M. (2002). Whence and Whither Money? In The Future of 
Money (pp. 31-72). Paris: OECD. Retrieved from https://www.oecd. org/futures/35391062.pdf

5. Barontini, Ch., \& Holden, $\mathrm{H}$. (2019). Proceeding with caution - a survey on central bank digital currency (BIS Paper No. 101). Retrieved from https://www.bis.org/ publ/bppdf/bispap101.pdf

6. Bech, M., \& Garratt, R. (2017). Central Bank Cryptocurrencies. BIS Quarterly Review, September, 55-70. Retrieved from https:// www.bis.org/publ/qtrpdf/r_ qt1709f.htm

7. Berger, H., de Haan, J., \& Eijffinger, S. C. W. (2001). Central Bank Independence: An Update of Theory and Practice. Journal of Economic Surveys, 15(1), 3-40. https://doi. org/10.1111/1467-6419.00131

8. Bindseil, U. (2020). Tiered $C B D C$ and the Financial System (ECB Working Paper No. 2351). Retrieved from https://www.ecb. europa.eu//pub/pdf/scpwps/ecb. wp2351 c8c18bbd60.en.pdf

9. BIS. (2019). Big Tech in Finance: Opportunities and Risks. In BIS Annual Economic Report. Chapter III. (pp. 55-79). Retrieved from https://www.bis.org/publ/arpdf/ ar2019e.pdf

10. Bodea, Cr., \& Hicks, R. (2014). Price Stability and Central Bank Independence: Discipline, Credibility and Democratic Institutions. International Organization, 69(1), 35-61. https://doi.org/10.1017/ S0020818314000277

11. Bordo, M., \& Levin, A. (2017). Central Banks Digital Currency and the Future of the Monetary Policy (NBER Working Paper. No. 23711). Retrieved from https:// www.nber.org/system/files/working_papers/w23711/w23711.pdf

12. Borio, C. (2019). On Money, Debt, Trust, and Central Banking (BIS Working Paper No. 763). Retrieved from https://www.bis.org/ publ/work763.htm

13. Carstens, A. (2018a). Money in Digital Age: 10 Thoughts (Speech). On Lee Kuan Yew School of Public Policy, Singapore, 15 November, 2018. Retrieved from https://www. bis.org/speeches/sp181115a.htm
14. Carstens, A. (2018b). Money in Digital Age: What the Role of Central Banks (Speech). On House of Finance of Goethe University, Frankfurt, 6 February, 2018. Retrieved from https://www.bis.org/ speeches/sp180206.pdf

15. Carstens, A. (2020). Shaping the Future of Payments. BIS Quarterly Review, March, 17-20. Retrieved from https://www.bis.org/publ/ qtrpdf/r_qt2003e.htm

16. Claeys, G., Demertzis, M., \& Efstathiou, K. (2018). Cryptocurrencies and monetary policy. IPOL. Retrieved from https://www.europarl.europa.eu/cmsdata/150000/ BRUEGEL_FINAL\%20publication.pdf

17. Committee on Payments and Market Infrastructures (CPMI). (2018). Central bank digital currencies (CPMI, Markets Committee Papers No. 174). Retrieved from https://www.bis.org/cpmi/ $\mathrm{publ} / \mathrm{d} 174 . \mathrm{htm}$

18. Cukierman, A. (2008). Central Bank Independence and Monetary Policymaking Institutions: Past, Present, and Future. European Journal of Political Economy, 24(4), 722-736. https://doi.org/10.1016/j. ejpoleco.2008.07.007

19. Demertzis, M., \& Wolff, B. (2018). The economic potential and risks of crypto assets: is a regulatory framework needed? (Policy Contribution Issue No.14). Retrieved from https://www.econstor.eu/bitstre am/10419/208022/1/1030937354. pdf

20. Dincer, N., \& Eichengreen, B. (2014). Central Bank Transparency and Independence: Updates and New Measures. International Journal of Central Banking, 10(1), 189-253. Retrieved from https:// ideas.repec.org/a/ijc/ijcjou/ y2014q1a6.html

21. Ehrentraud, J., Ocampo, D. G., Garzoni, L., \& Piccolo, M. (2020). Policy responses to FinTech: a crosscountry overview. BIS Financial Stability Institute Insights. Retrieved from https://www.bis.org/ fsi/publ/insights23.htm

22. Eichengreen, B. (2018). Why 'Stable Coins' Are Not Answer to
Bitcoin's Instability. The Guardian Retrieved from https://www.theguardian.com/technology/2018/ sep/11/stable-coins-bitcoin-cryptocurrencies-tether

23. Fehr, E., Fischbacher, U., Schupp, U., von Rosenbladt, B., \& Wagner G. G. (2003). A Nation-Wide Laboratory: Examining Trust and Trustworthiness by Integrating Behavioral Experiments into Representative Surveys (CEPR Discussion Paper No. 3858). Retrieved from http://ftp.iza.org/dp715.pdf

24. Frost, J. (2020). The economic forces driving FinTech adoption across countries (BIS Working Paper No. 838). Retrieved from https://www. bis.org/publ/work838.htm

25. Gandal, N., \& Sussman, N. (1997). Asymmetric Information and Commodity Money: Tickling the Tolerance in Medieval France. Journal of Money, Credit, and Banking, 29(4), 440-457. Retrieved from https://ideas.repec.org/a/ mcb/jmoncb/v29y1997i4p440-57. $\mathrm{html}$

26. Gomez, G. (2019). Money as an Institution: Rule versus Evolved Practice? Analysis of Multiple Currencies in Argentina. Journal of Risk and Financial Management, 12(2), 1-14. Retrieved from https:// repub.eur.nl/pub/116457

27. Gross, M., \& Siebenbrunner, Ch. (2019). Money Creation in Fiat and Digital Currency Systems (IMF Working Paper No. WP/19/285). http://dx.doi. org/10.5089/9781513521565.001

28. Hayo, B., \& Voigt, S. (2008). Inflation, Central Bank Independence and the Legal System. Journal of Institutional and Theoretical Economics, 164(4), 751-777. Retrieved from https:// econpapers.repec.org/article/ mhrjinste/urn_3asici_3a09324569(200812)164_3a4_5f751_3aic biat_5f2.0.tx_5f2-1.htm

29. Keeper, P., \& Stasavage, D. (2003). The Limits of Delegation: Veto Players, Central Bank Independence, and the Credibility of Monetary Policy. American Political Science Review, 97(3), 593-621. https://doi.org/10.1017/ S0003055403000777 
30. Kliff, J., Alwazir, J., Davidovic, S., Farias, A., Khan, A., Khiaonarong, T., Malaika, M., Monroe, H., Sugimoto, N., Tourpe, H., \& Zhou, P. (2020). A Survey of Research on Retail Central Bank Digital Currency (IMF Working Paper No. WP/20/104). Retrieved from https://www. imf.org/en/Publications/WP/ Issues/2020/06/26/A-Surveyof-Research-on-Retail-CentralBank-Digital-Currency-49517

31. Kocherlakota, N. (1996). Money is Memory (Research Department Staff Report No. 218). Federal Reserve Bank of Minneapolis. Retrieved from https://www. minneapolisfed.org/research/staffreports/money-is-memory

32. Kocherlakota, N. (1998). Money is Memory. Journal of Economic Theory, 81(2), 232-251. https://doi. org/10.1006/jeth.1997.2357

33. Lewis, D. (1969). Convention: $a$ Philosophical Study. NY.: Wiley.

34. Mancini-Griffoli, T., Martinez Peria, M. S., Agur, I., Ari, A., Kiff, J., Popescu, A., \& Rochon, C. (2018). Casting Light on Central Bank Digital Currency (IMF Staff Discussion Notes No. 18/08). Retrieved from https://www.imf.org/ en/Publications/Staff-DiscussionNotes/Issues/2018/11/13/CastingLight-on-Central-Bank-DigitalCurrencies-46233

35. Milgrom, S., \& Stokey, N. (1982). Information, Trade and Common Knowledge. Journal of Economic Theory, 26(1), 17-27. https://doi. org/10.1016/0022-0531(82)900461

36. Moser, P. (1999). Cheks and Balances, and the Supply of Central Bank Independence. European Economic Review, 43(8), 15691593. https://doi.org/10.1016/ S0014-2921(98)00045-2

37. Nurbayev, D. (2017). The Rule of Law, Central Bank Independence and Price Stability. Journal of Institutional Economics, 14(4), 659-687. https://doi.org/10.1017/ S1744137417000261

38. Quinn, S., \& Roberds, W. (2014). How Amsterdam Got Fiat Money. Journal of Monetary
Economics, 66(C), 1-12. https:// doi.org/10.1016/j.jmoneco.2014.03.004

39. Raskin, M., \& Yermack, D. (2016). Digital Currencies, Decentralized Ledgers, and the Future of Central Banking (NBER Working Paper No. 22238). Retrieved from https://www.nber.org/system/files/ working_papers/w22238/w22238. pdf

40. Samuelson, P. (1958). An Exact Consumption-Loan Model of Interest with and without the Social Contrivance of Money. Journal of Political Economy, 66(6), 467-482. http://dx.doi.org/10.1086/258100

41. Sargent, Th., \& Smith, B. (1997). Coinage, Debasement, and Gresham's Laws. Economic Theory, 10(2), 197-226. Retrieved from https:// www.jstor.org/stable/25055035

42. Sargent, Th., \& Wallace, M. (1983). A Model of Commodity Money. Journal of Monetary Economics, 12(1), 163-182. Retrieved from https://ideas.repec.org/a/eee/ moneco/v12y1983ilp163-187. html

43. Schnabel, I., \& Shin, H. S. (2004). Liquidity and Contagion: The Crisis of 1763. Journal of the European Economic Association, 2(6), 1-40. https://doi. org/10.1162/1542476042813887

44. Schnabel, I., \& Shin, H. S. (2018). Money and Trust: Lessons from the 1620s for Money in the Digital Age (BIS Working Paper. No. 698). Retrieved from https://www.bis. org/publ/work698.htm

45. Simmel, G. (1990). The Philosophy of Money ( $2^{\text {nd }}$ ed.). L.: Routledge.

46. The Financial Times. (2020). Poll Reveals Public Distrust for Big Tech's Digital Money Plans. Official Monetary and Financial Institutions Forum. Retrieved from https://www.ft.com/content/ e0079d72-474d-11ea-aeb3$955839 \mathrm{e} 06441$

47. Tucker, P. (2017). The Political Economy of Central Banking in the Digital Age (SUERF Policy Note No. 13). Retrieved from https://www.hks.harvard.edu/ centers/mrcbg/publications/awp/ tucker_suerf
48. Vaz, J., \& Brown, K. (2020). Money Without Institutions, How Can Cryptocurrencies be Trusted? Paper presented on Financial Engineering and Banking Society Conference. Prague. Retrieved from https://www. efmaefm.org/0EFMAMEETINGS/ EFMA\%20ANNUAL\%20 MEETINGS/2020-Dublin/papers/ EFMA\%202020_stage-1301_question-Full\%20Paper_id-207.pdf

49. Yermack, D. (2017). Corporate Governance and Blockchains. Review of Finance, 21(1), 7-31. https://doi.org/10.1093/rof/rfw074

50. Zanini, M., \& Migueles, C. (2013). Trust as an Element of Informal Coordination and its Relationship with Organizational Performance. EconomiA, 14(2), 77-87. https://doi.org/10.1016/j. econ.2013.08.005

51. Zelizer, V. (1994). The Social Meaning of Money. NY.: Basic Books.

52. Zucker, L. (1986). Production of Trust: Institutional Sources of Economic Structure, 18401920. Research in Organizational Behavior, 8, 53-111. Retrieved from https://psycnet.apa.org/record/1988-10420-001 


\section{APPENDIX A. POLITICAL-INSTITUTIONAL FACTORS}

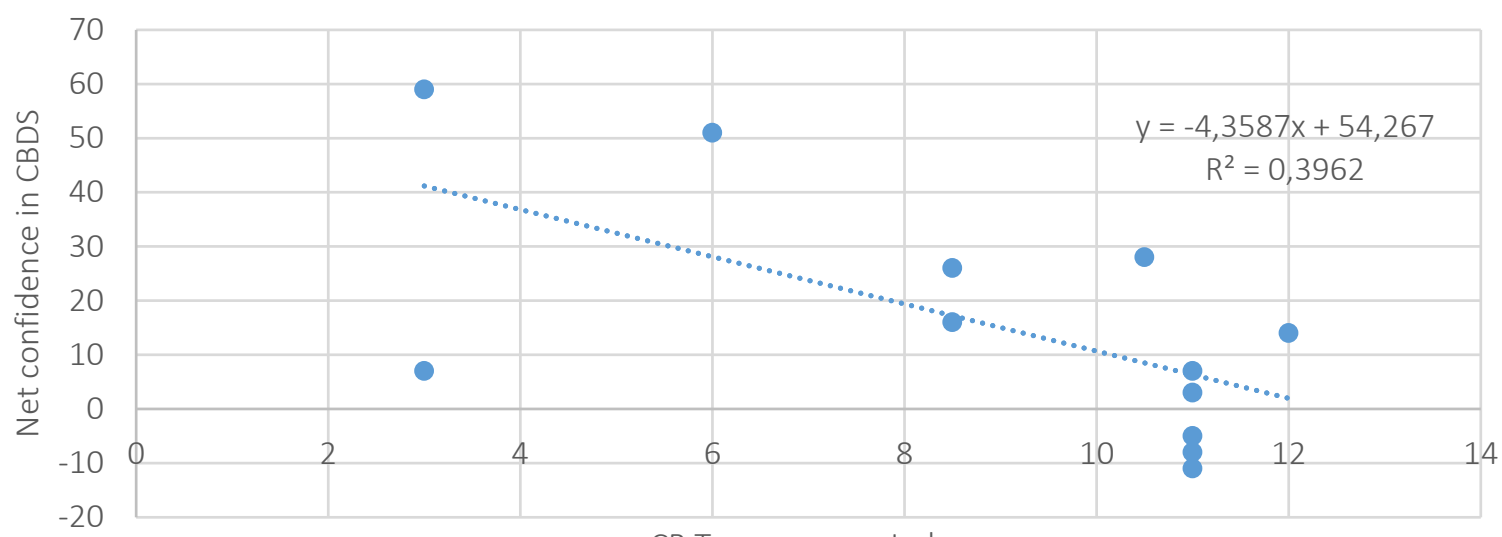

CB Transparency Index

Figure A1. Confidence in CBDC and central bank transparency

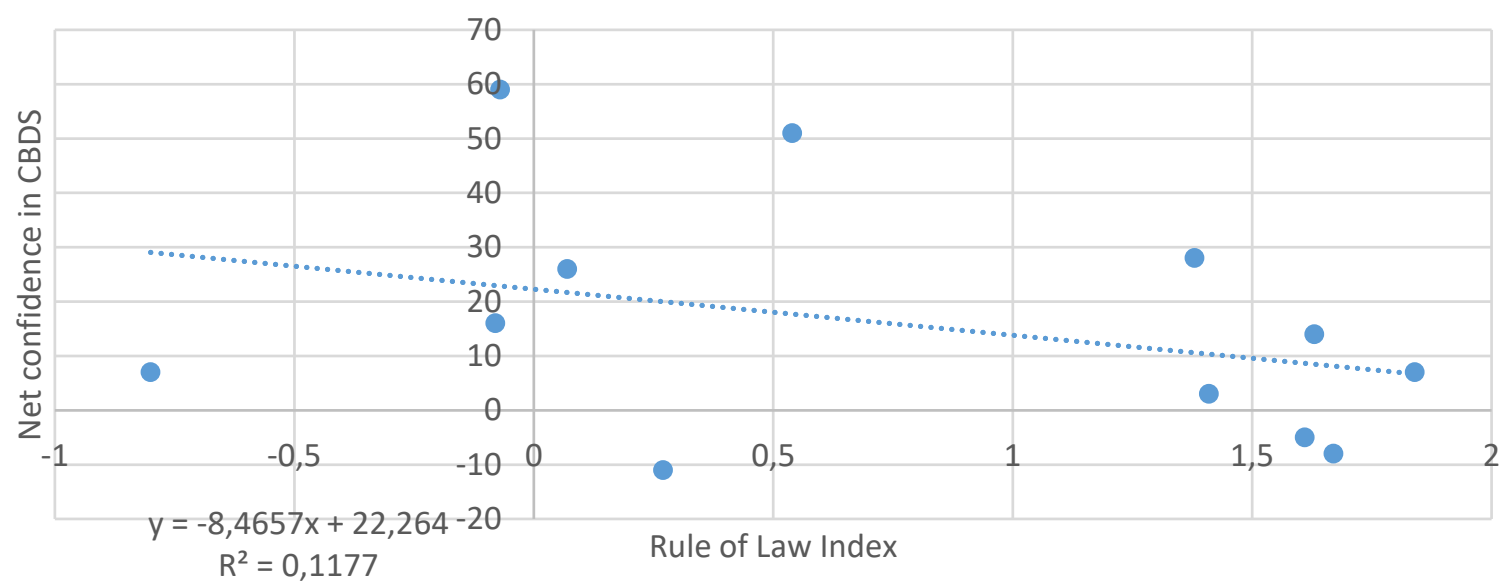

Figure A2. Confidence in CBDC and the rule of law

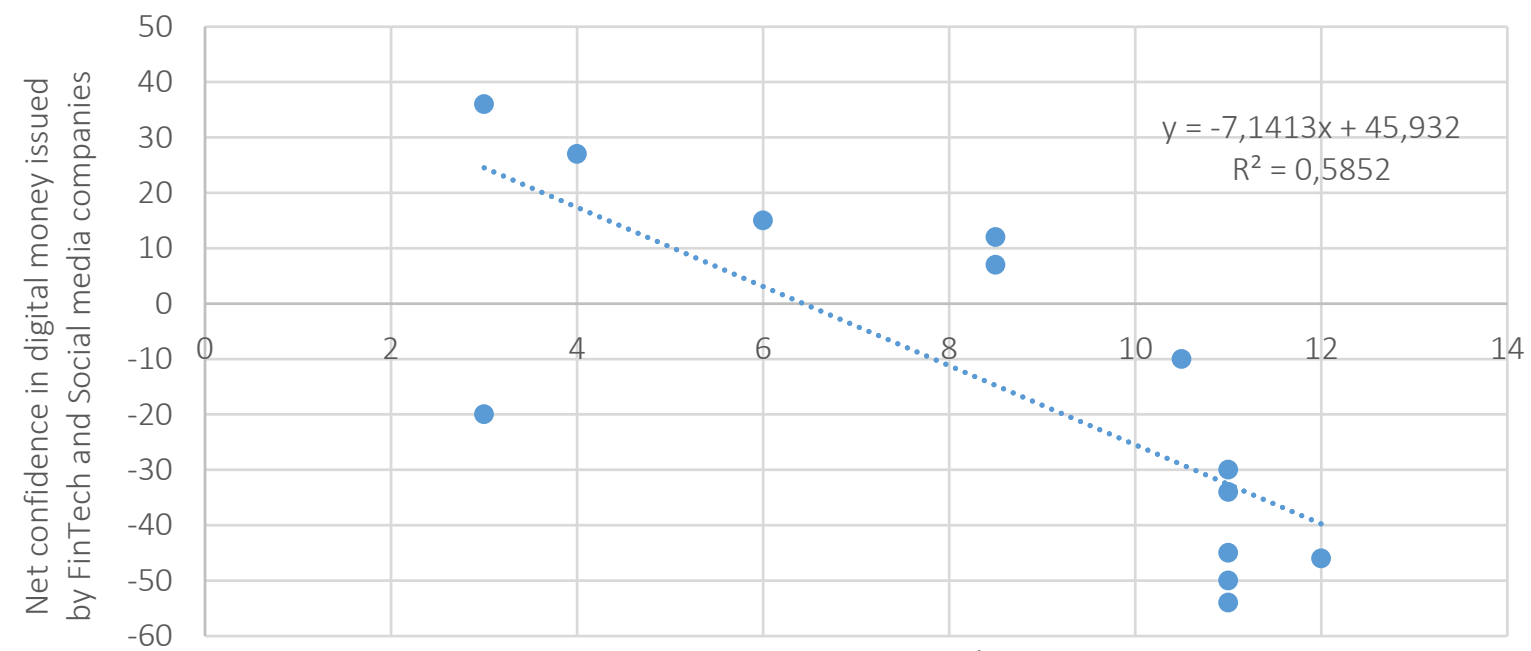

CB Transparency Index

Figure A3. Confidence in privately issued digital money and central bank transparency 


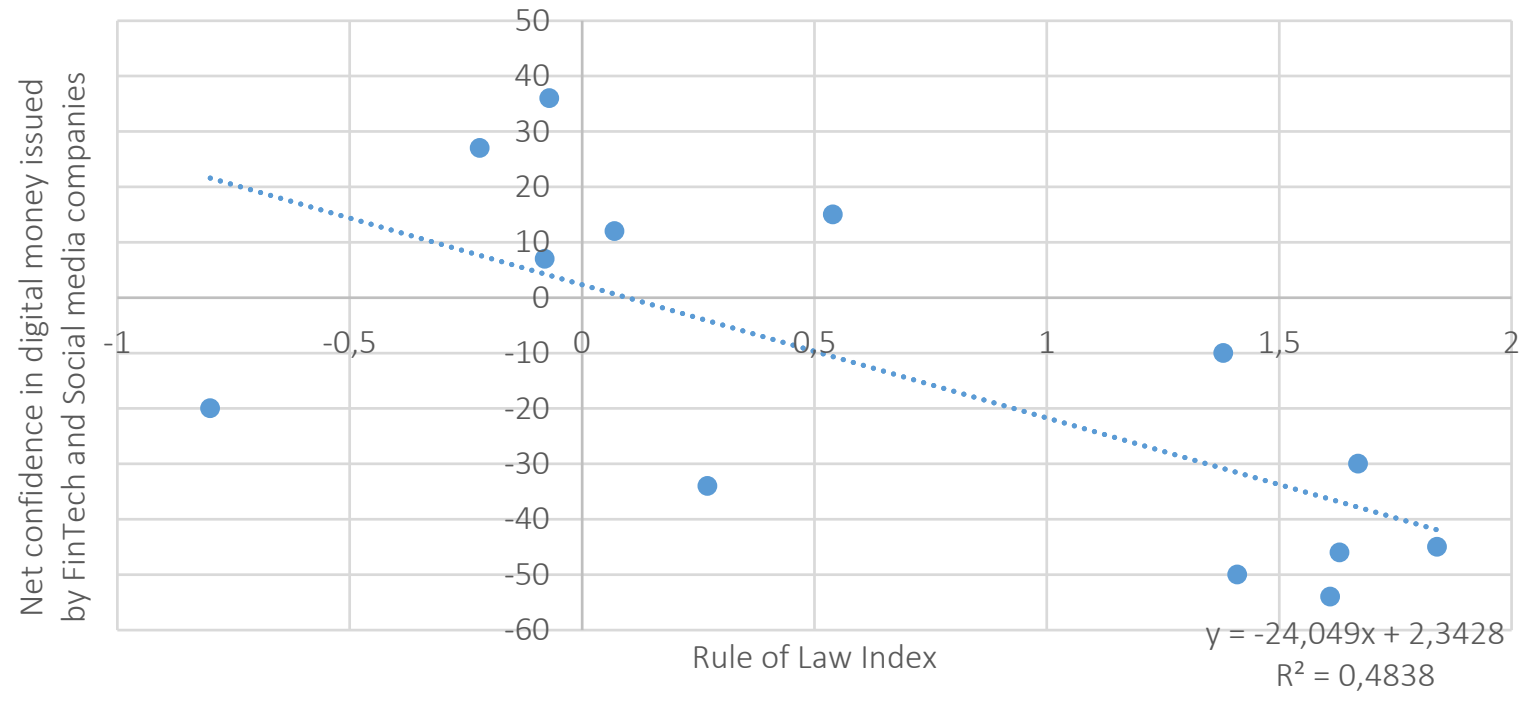

Figure A4. Confidence in privately issued digital money and the rule of law

\section{APPENDIX B. EFFICIENCY OF SOCIAL INTERACTION FACTORS}

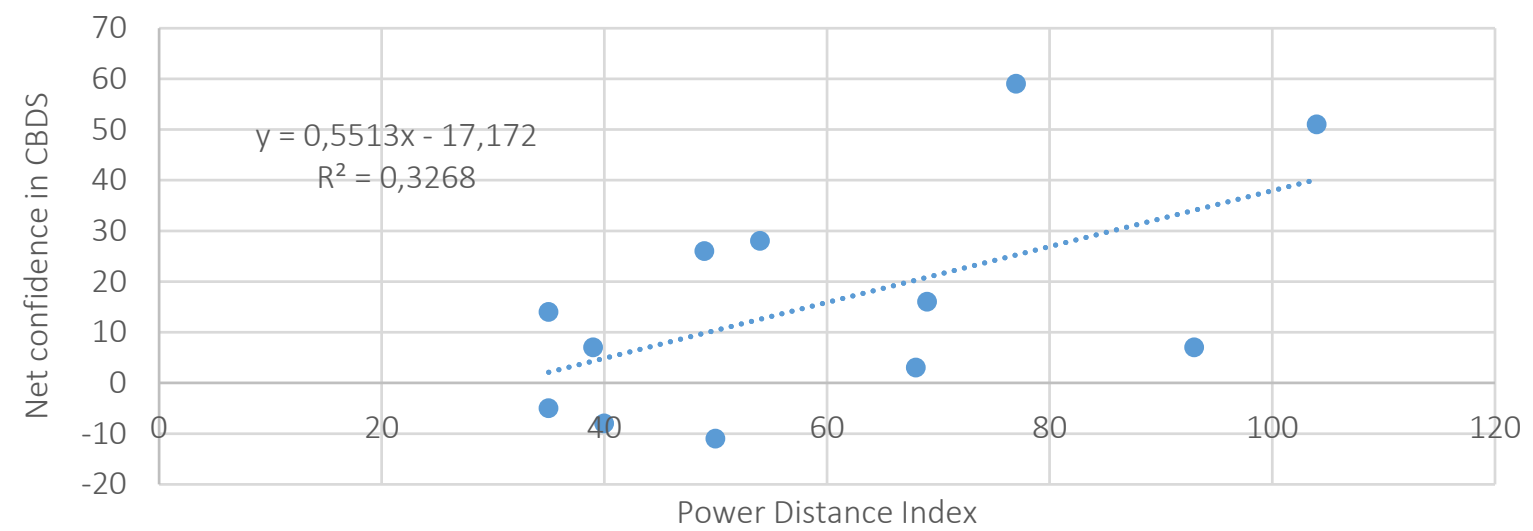

Figure B1. Confidence in CBDC and power distance

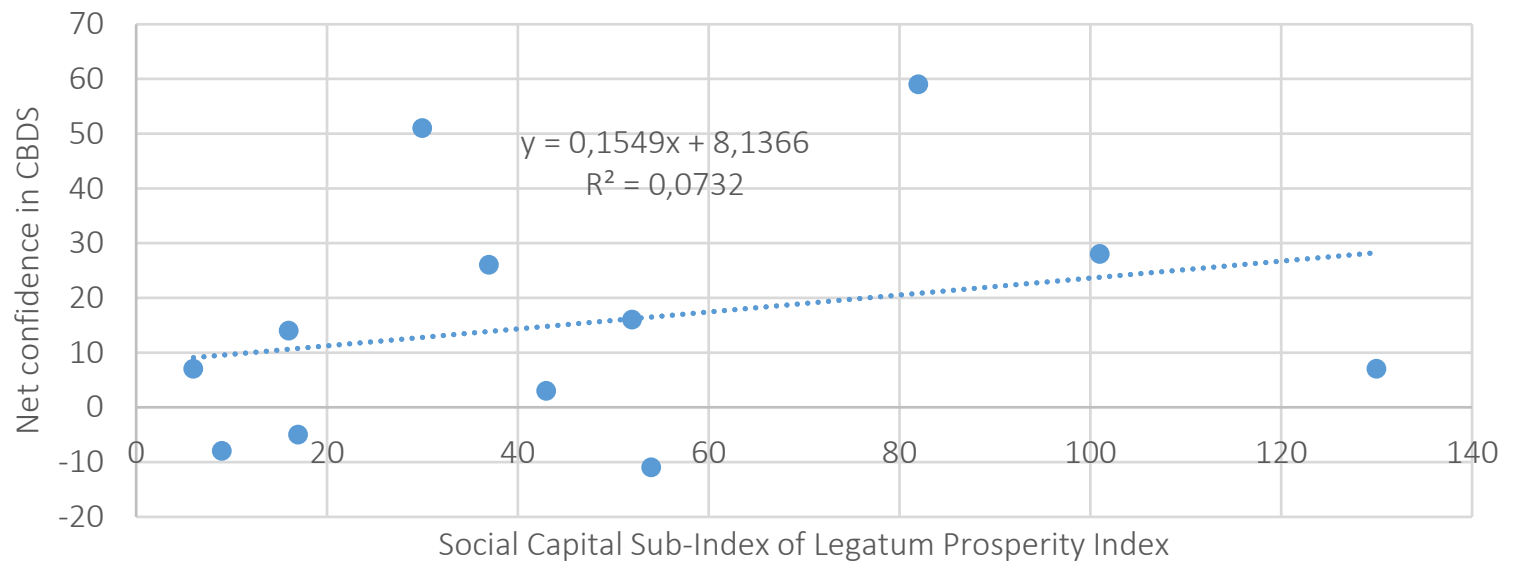

Figure B2. Confidence in CBDC and social capital 


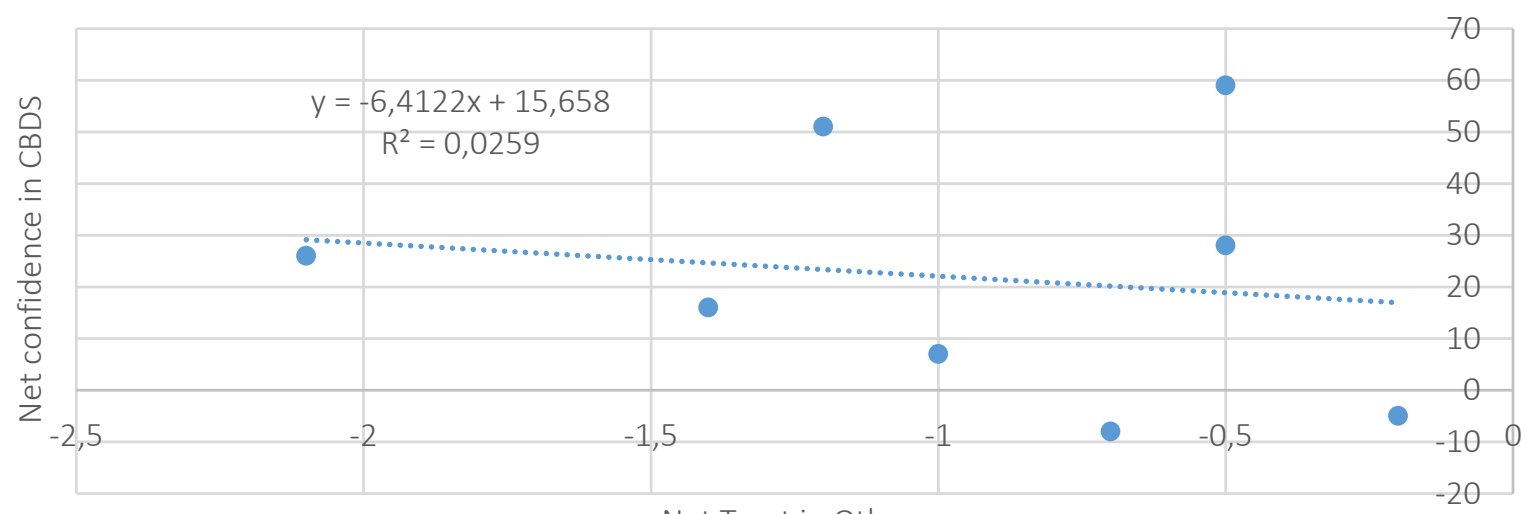

Net Trust in Others

Figure B3. Confidence in $\mathrm{CBDC}$ and social trust

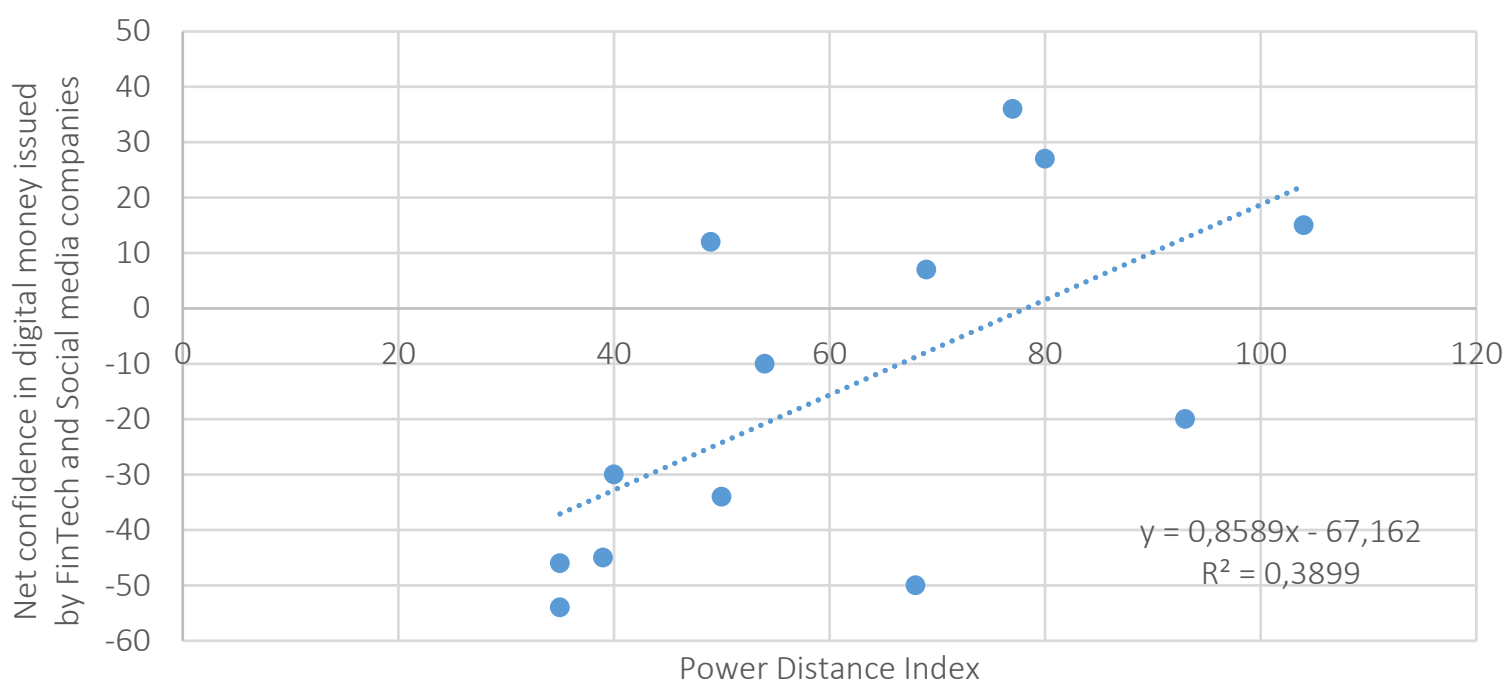

Figure B4. Confidence in privately issued digital money and power distance

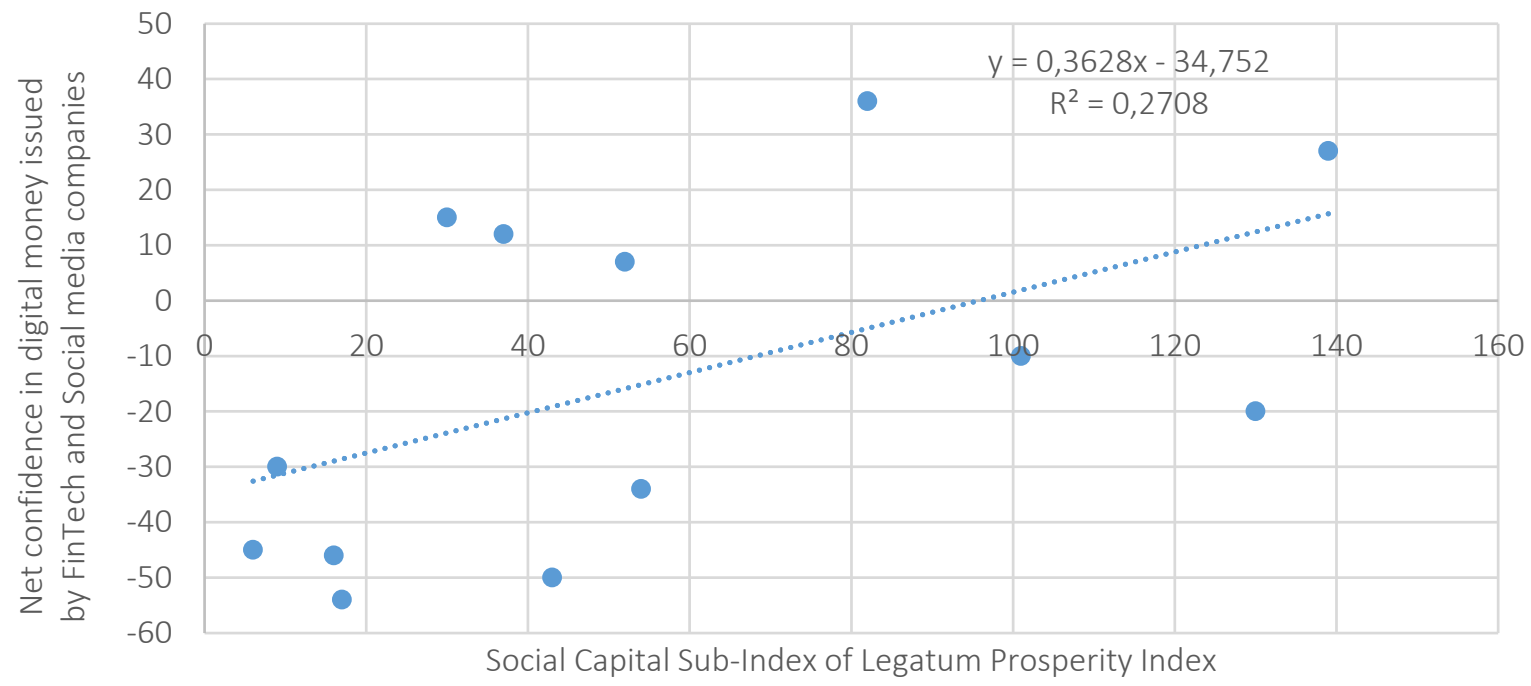

Figure B5. Confidence in privately issued digital money and social capital 


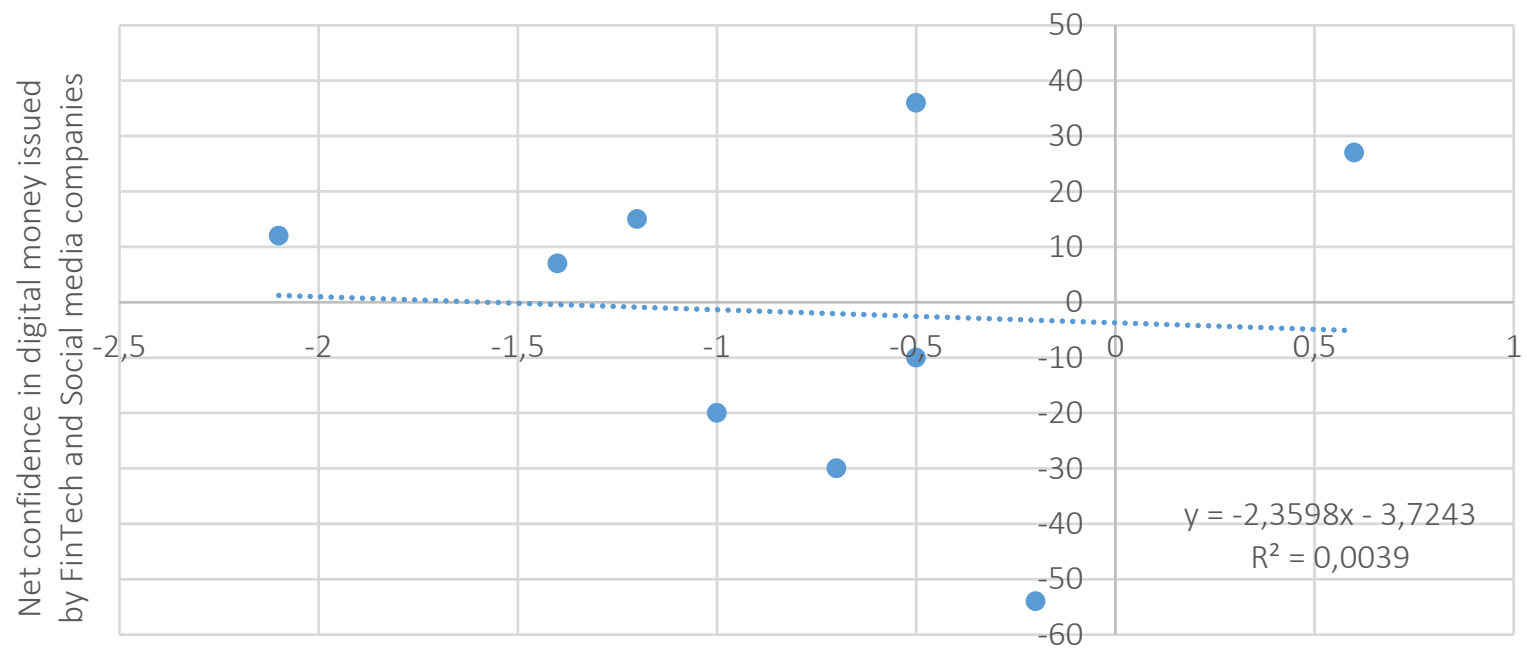

Net Trust in Others

Figure B6. Confidence in privately issued digital money and social trust

\section{APPENDIX C. FACTORS SUPPORTING DIGITALIZATION}

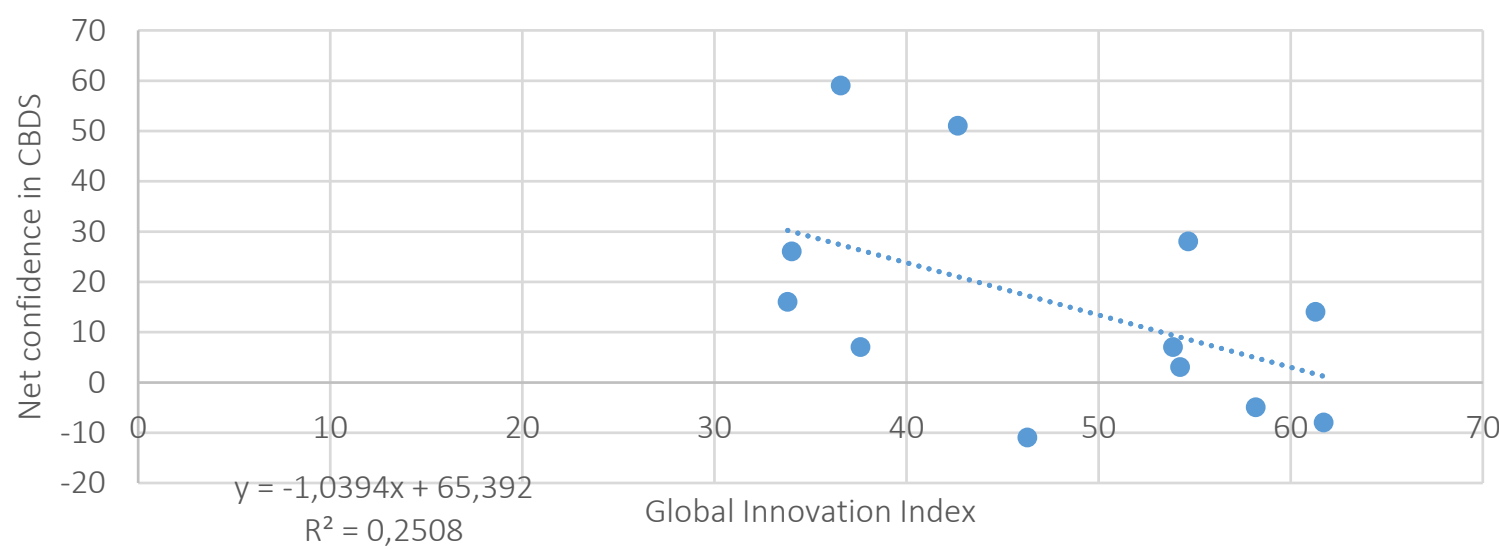

Figure C1. Confidence in CBDC and innovations

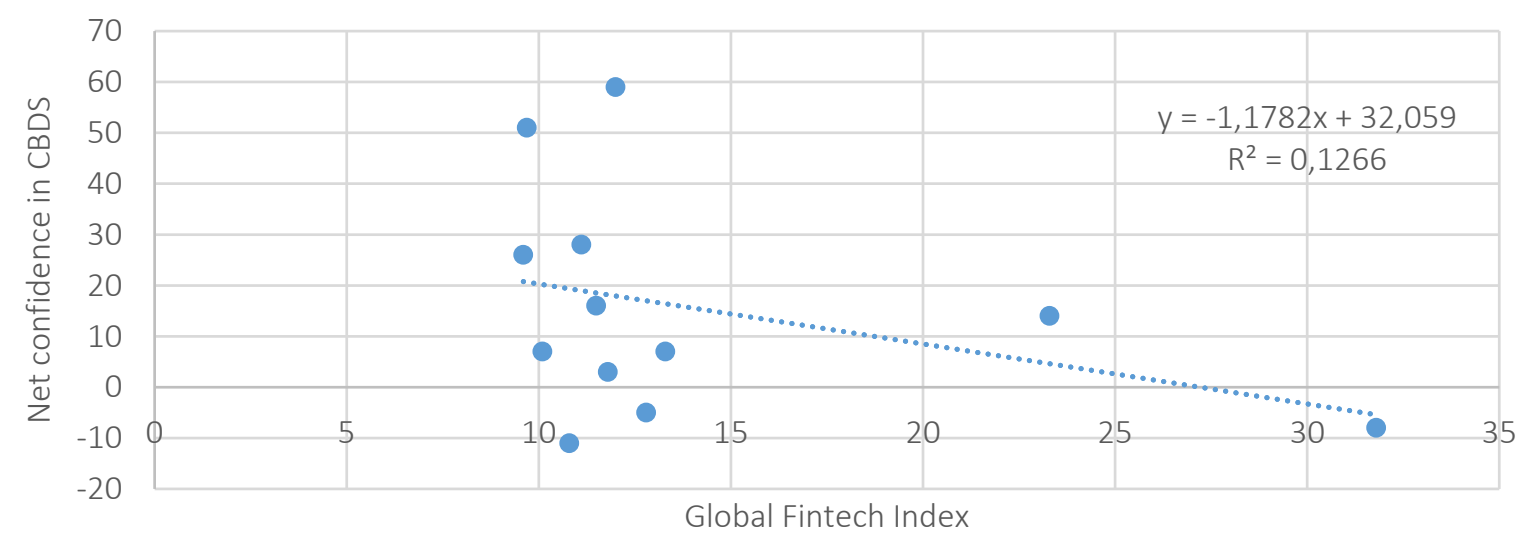

Figure C2. Confidence in $\mathrm{CBDC}$ and FinTech development 


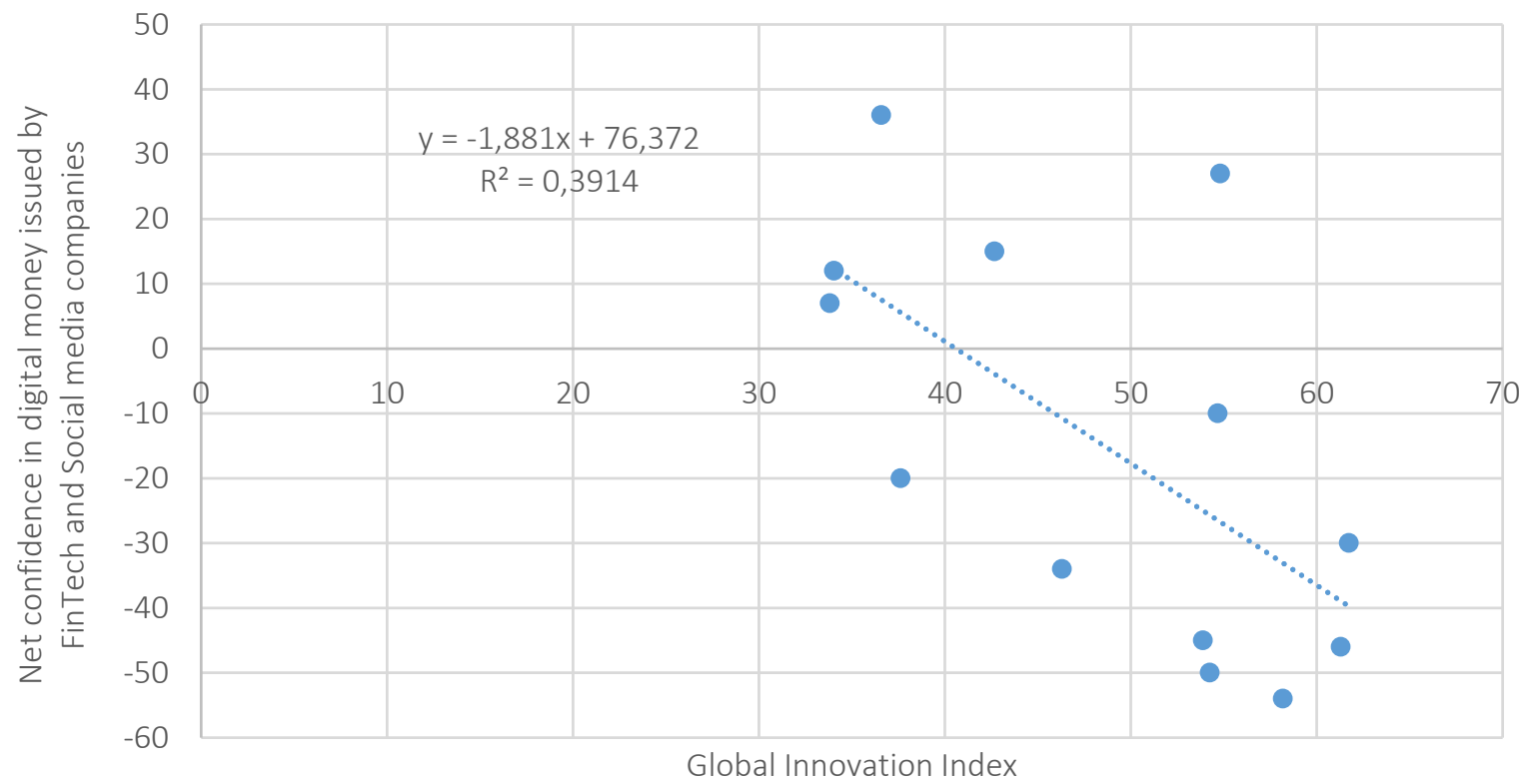

Figure C3. Confidence in privately issued digital money and innovations

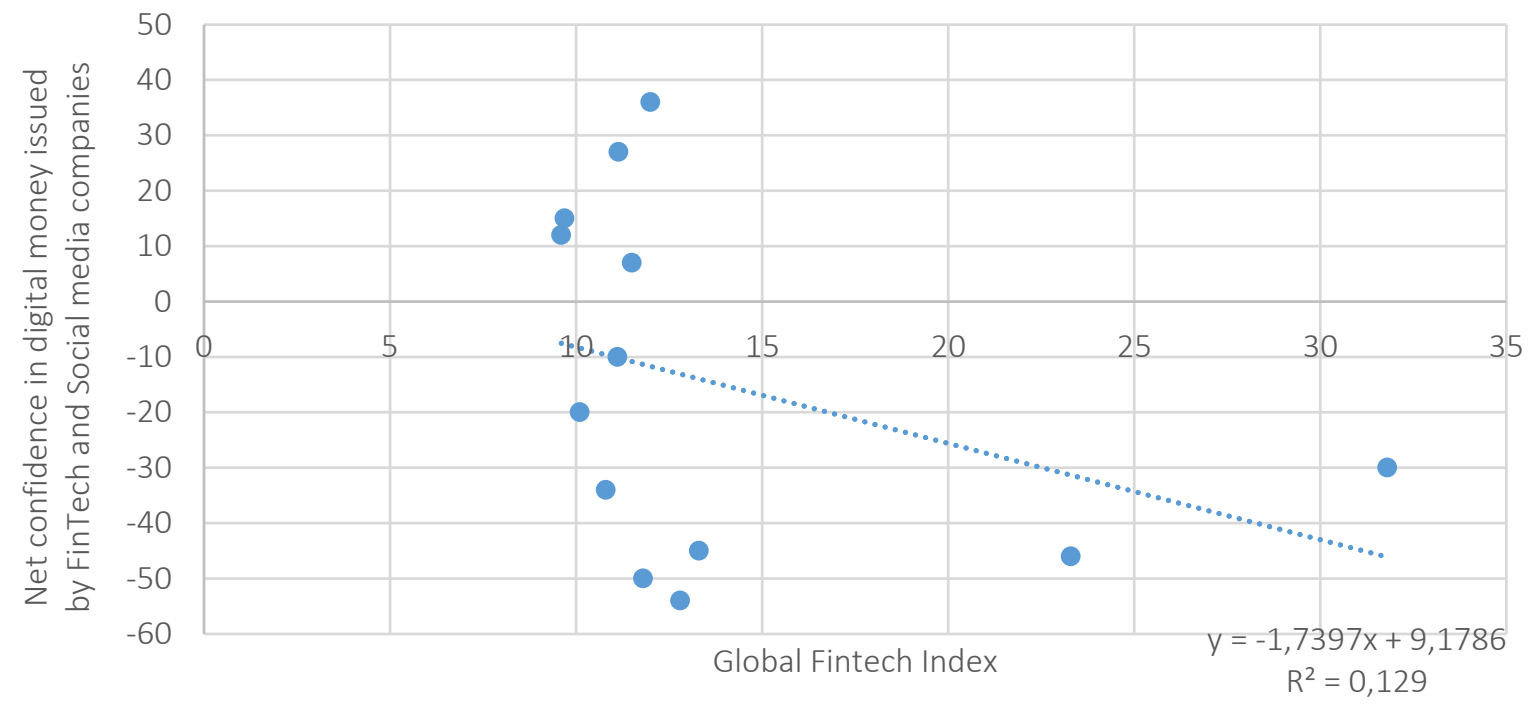

Figure C4. Confidence in privately issued digital money and FinTech development 


\section{APPENDIX D. FACTORS OF INFLATIONARY EXPERIENCE}

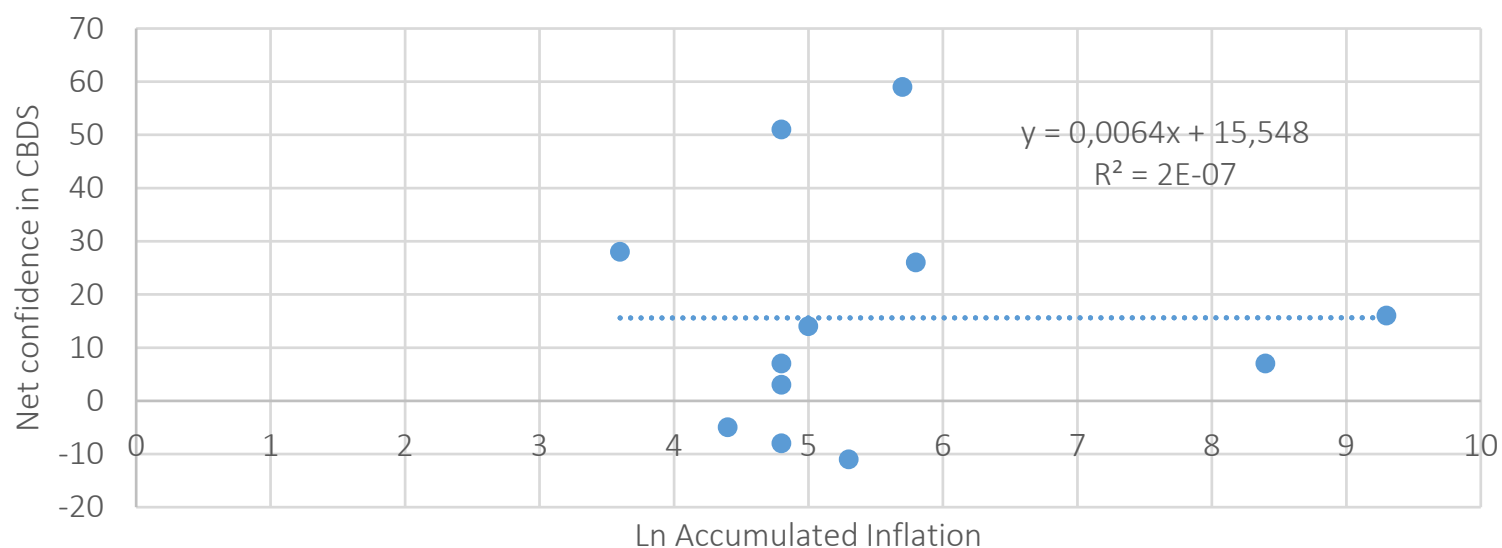

Figure D1. Confidence in CBDC and inflationary experience

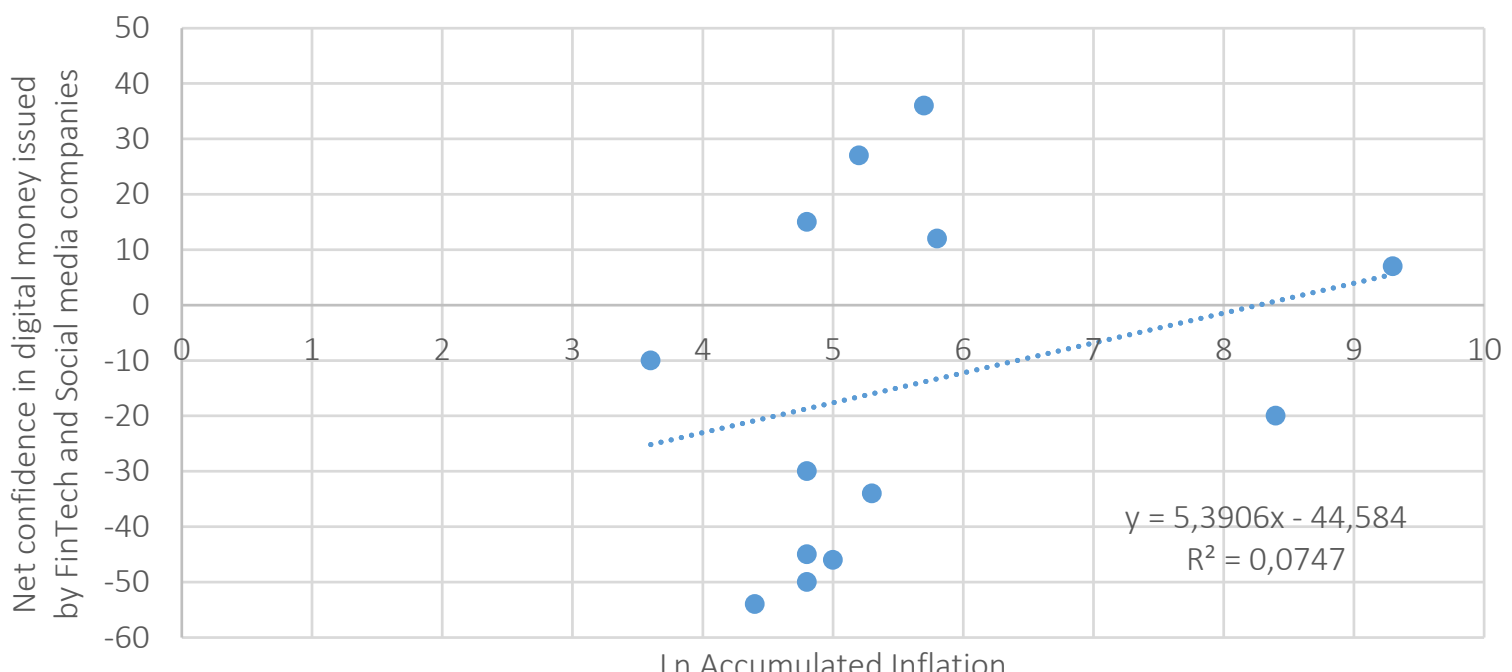

Ln Accumulated Inflation

Figure D2. Confidence in privately issued digital money and inflationary experience 


\section{APPENDIX E. DEMOGRAPHIC FACTORS}

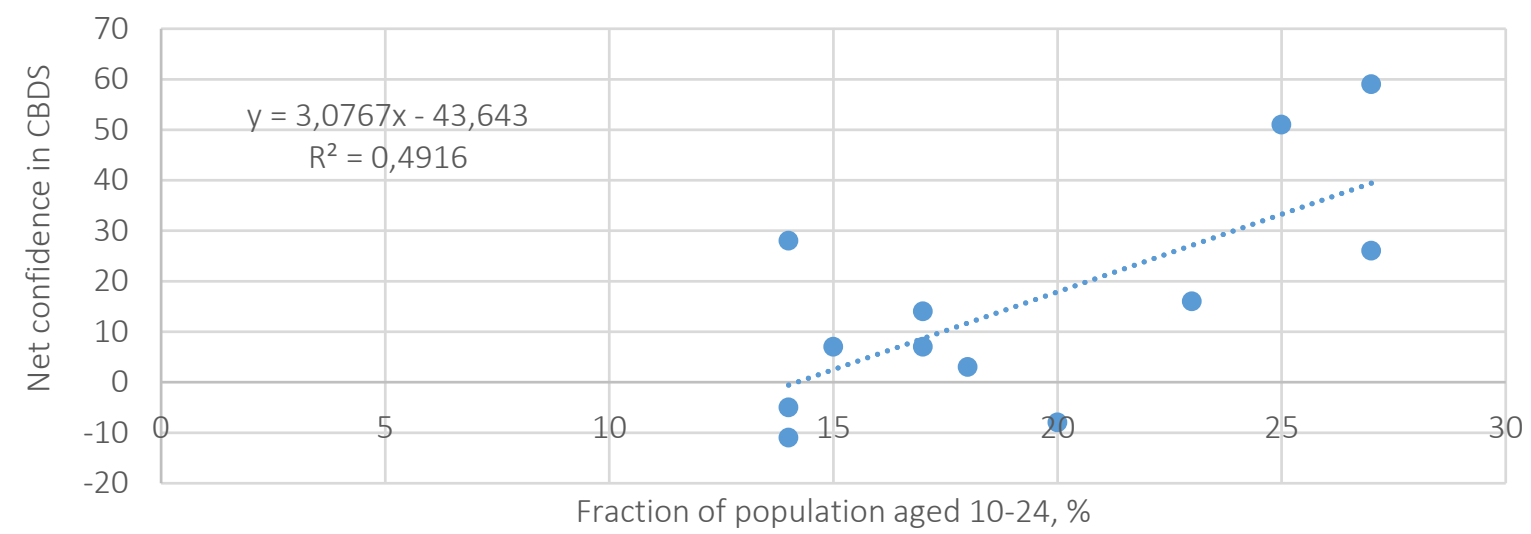

Figure E1. Confidence in CBDS and the fraction of younger generation

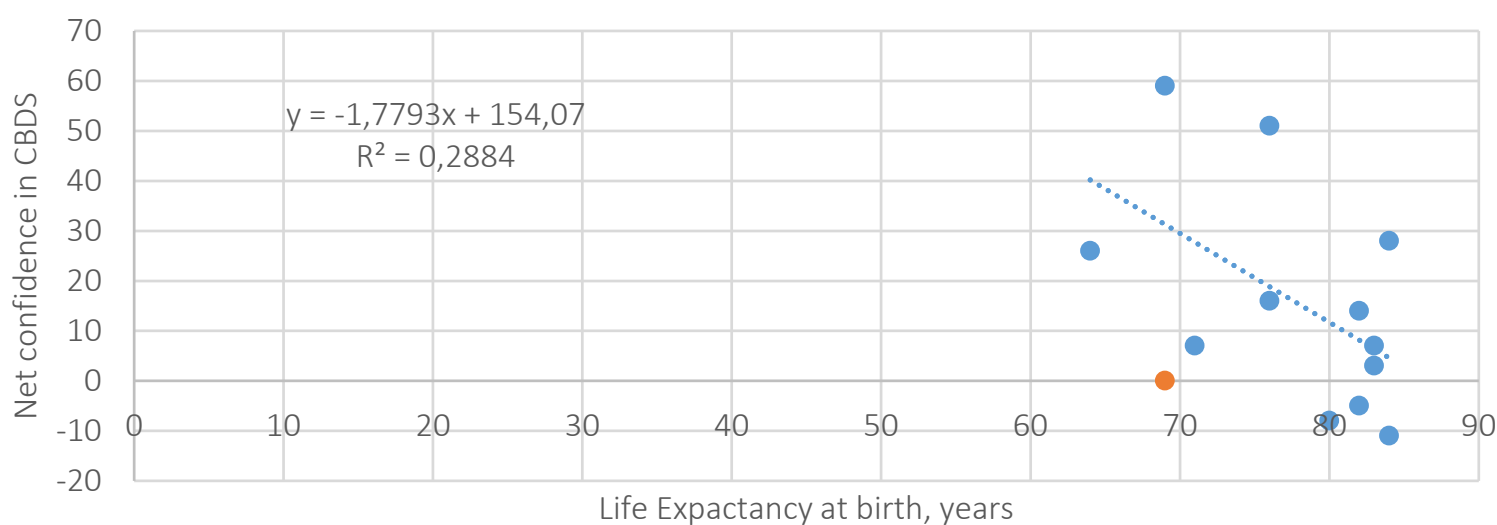

Figure E2. Confidence in CBDS and life expectancy

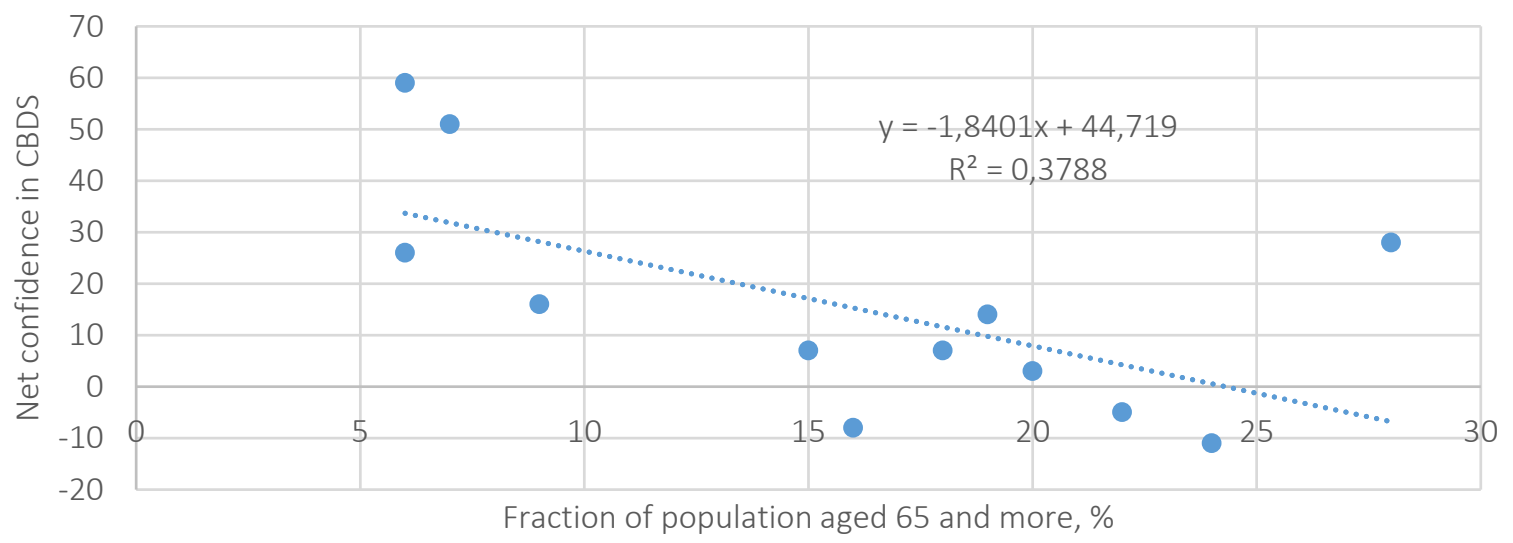

Figure E3. Confidence in CBDC and the fraction of older generation 


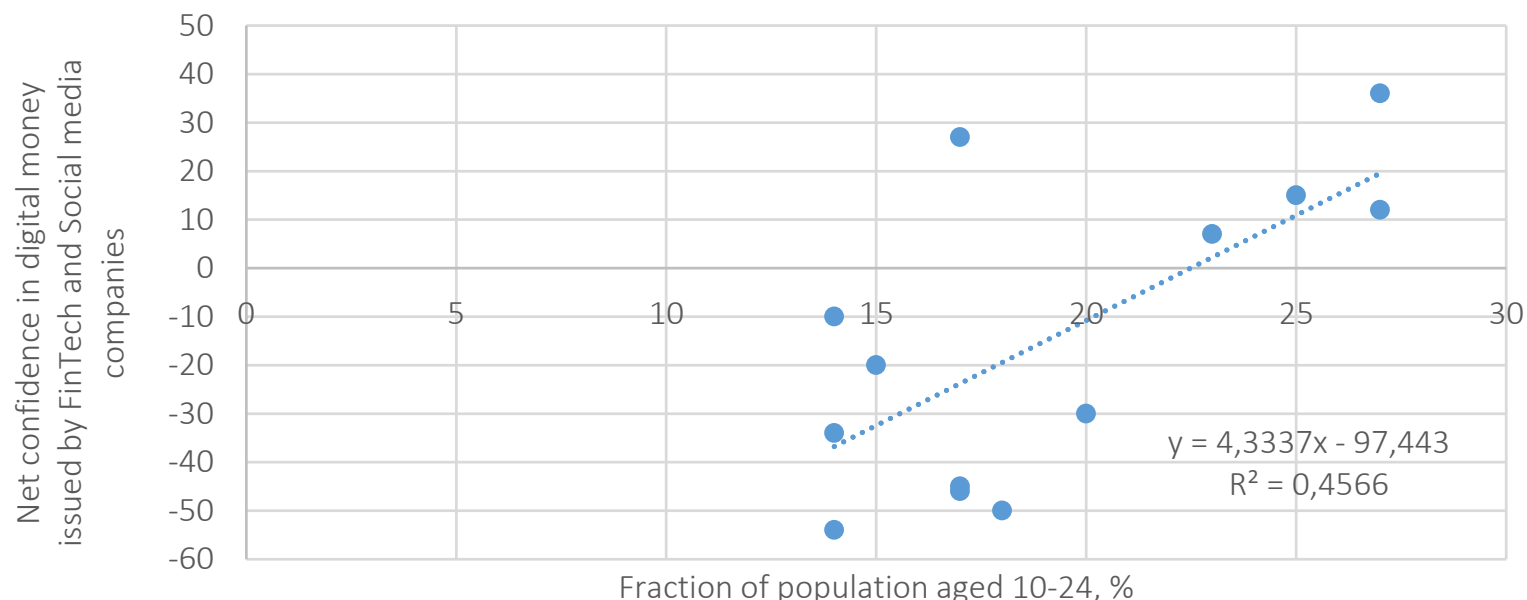

Figure E4. Confidence in privately issued digital money and the fraction of younger generation

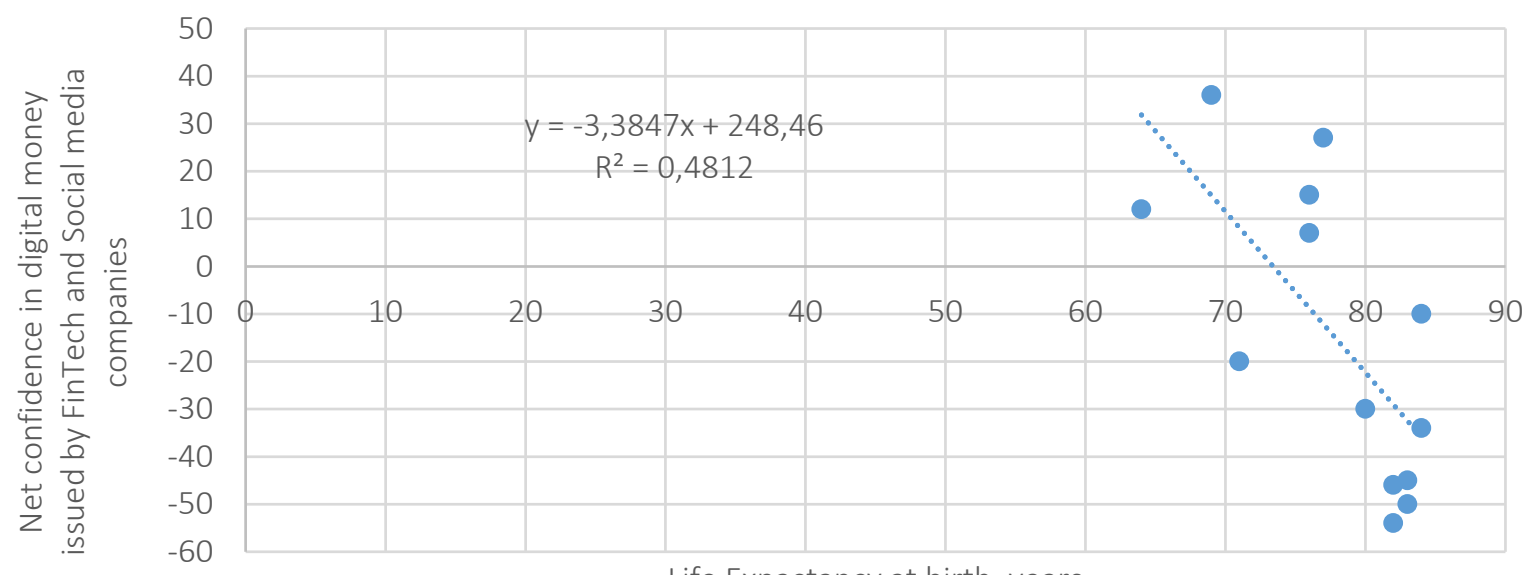

Life Expactancy at birth, years

Figure E5. Confidence in privately issued digital money and life expectancy

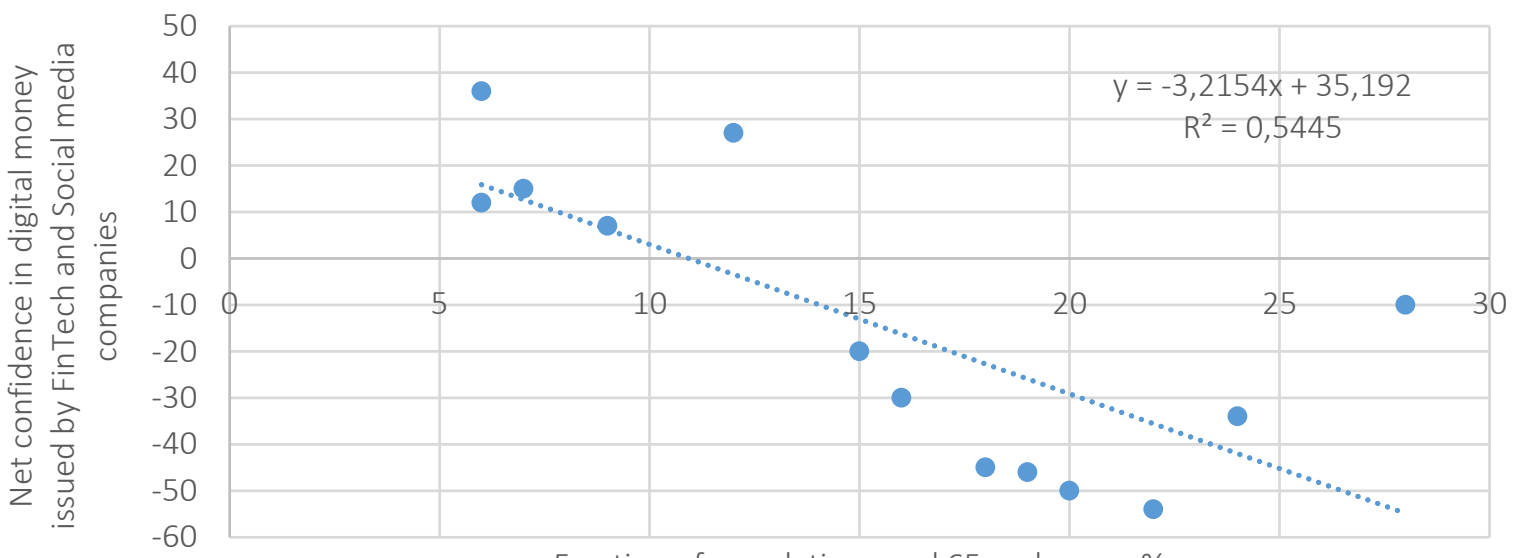

Fraction of population aged 65 and more, $\%$

Figure E6. Confidence in privately issued digital money and the fraction of older generation 